\title{
Effectiveness of IT Service Management Capability Value Co-Creation and Value Facilitation Mechanisms
}

Winkler, Till J.; Wulf, Jochen

Document Version

Accepted author manuscript

Published in:

Journal of Management Information Systems

DOI:

10.1080/07421222.2019.1599513

Publication date:

2019

License

Unspecified

Citation for published version (APA):

Winkler, T. J., \& Wulf, J. (2019). Effectiveness of IT Service Management Capability: Value Co-Creation and Value Facilitation Mechanisms. Journal of Management Information Systems, 36(2), 639-675.

https://doi.org/10.1080/07421222.2019.1599513

Link to publication in CBS Research Portal

\section{General rights}

Copyright and moral rights for the publications made accessible in the public portal are retained by the authors and/or other copyright owners and it is a condition of accessing publications that users recognise and abide by the legal requirements associated with these rights.

Take down policy

If you believe that this document breaches copyright please contact us (research.lib@cbs.dk) providing details, and we will remove access to the work immediately and investigate your claim. 


\title{
Effectiveness of IT Service Management Capability: Value Co-Creation and Value Facilitation Mechanisms
}

\author{
Till J. Winkler and Jochen Wulf
}

Journal article (Accepted manuscript*)

\section{Please cite this article as:}

Winkler, T. J., \& Wulf, J. (2019). Effectiveness of IT Service Management Capability: Value Co-Creation and Value Facilitation Mechanisms. Journal of Management Information Systems, 36(2), 639-675. https://doi.org/10.1080/07421222.2019.1599513

This is an Accepted Manuscript of an article published by Taylor \& Francis in Journal of Management Information Systems on 14 Jun 2019, available online:

DOI: http://www.tandfonline.com/10.1080/07421222.2019.1599513

* This version of the article has been accepted for publication and undergone full peer review but has not been through the copyediting, typesetting, pagination and proofreading process, which may lead to differences between this version and the publisher's final version AKA Version of Record.

Uploaded to CBS Research Portal: August २०२० 


\title{
Effectiveness of IT Service Management Capability: Value Co-Creation and Value Facilitation Mechanisms
}

\section{Accepted manuscript version (postprint) and supplements}

$\begin{array}{lll}\text { Name: } & \text { Till J. Winkler } & \text { Jochen Wulf } \\ \text { Affiliation: } & \begin{array}{l}\text { Department of Digitalization } \\ \text { Copenhagen Business School }\end{array} & \begin{array}{l}\text { Institute of Information Management } \\ \text { University of St.Gallen }\end{array} \\ \text { Address: } & \text { Howitzvej 60 } & \text { Mueller Friedberg Strasse 8 } \\ & \text { 2000 Frederiksberg } & 9000 \text { St. Gallen } \\ & \text { Denmark } & \text { Switzerland } \\ \text { Email: } & \text { winkler@cbs.dk } & \text { jochen.wulf@unisg.ch }\end{array}$

\section{Cite as}

Till J. Winkler \& Jochen Wulf (2019) Effectiveness of IT Service Management Capability: Value CoCreation and Value Facilitation Mechanisms, Journal of Management Information Systems, 36:2, 639675, DOI: $\underline{10.1080 / 07421222.2019 .1599513}$

\begin{abstract}
Information technology service management (ITSM) has become the prevalent management approach to the provision of IT services worldwide. Researchers and practitioners, however, still lack an understanding regarding through which mechanisms and in which strategic contexts an ITSM capability contributes most to information systems (IS) effectiveness. Grounded in a service-dominant logic, we hypothesize that ITSM capability contributes to IS effectiveness through sustaining the alignment of the IS function with the business and contingent upon organizational IS strategic conservativeness. Data collected from 256 organizations confirms that direct effects from ITSM capability are mediated by ISbusiness alignment and strengthened by IS strategic conservativeness. Our findings provide evidence for a co-occurrence of value co-creation and value facilitation mechanisms in internal IT service relationships and for a greater value of ITSM capability in stable strategic contexts. Overall, our results contribute a novel understanding to the service literature of the distinct mechanisms and the facilitating contextual contingencies of value creation in IT service relationships.
\end{abstract}

Keywords and phrases: Information technology service management (ITSM), service-dominant logic, information systems (IS) effectiveness, IS-business alignment, IS strategy, IS conservative, value co-creation, value facilitation 


\section{ABOUT THE AUTHORS}

TILL J. WINKLER is an Associate Professor of Information Technology Management and Digitalization in the Department of Digitalization at the Copenhagen Business School, Denmark. Prior to obtaining a Ph.D. in Information Systems from Humboldt University of Berlin, Germany, he worked as a management consultant at Capgemini's Chief Information Officer Advisory Services. His research on IT governance, cloud computing, and digital health has been presented at major Information Systems conferences and appeared in journals including Journal of Management Information Systems, MIS Quarterly Executive, Health Policy and Technology, and others. He was awarded Journal of Strategic Information Systems reviewer of the year 2016 and serves on the editorial board of Business \& Information Systems Engineering.

JOCHEN WULF is a lecturer at the Institute of Information Management, University of St.Gallen, Switzerland. He was awarded a grant of the International Postdoctoral Fellowship program while being an assistant professor at the University of St.Gallen. He obtained a Ph.D. in Information Systems from the Technical University of Berlin, Germany. His research on socio-technical aspects of big data analytics, consumer-centric information systems, and IT service management has been published in journals such as Information Systems Journal, Information \& Management, MIS Quarterly Executive, Business \& Information Systems Engineering and Electronic Markets. He has several years of consulting experience in the areas of IT service management, digital consumer services, and business analytics.

Footnote: The authors acknowledge the JMIS Editor-in-Chief, the Associate Editor, and the anonymous reviewers for their valuable contributions during the review process. 


\section{TABLE OF CONTENTS}

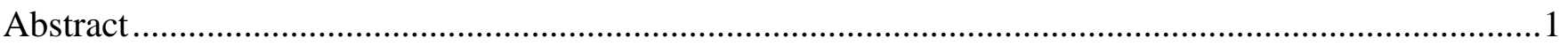

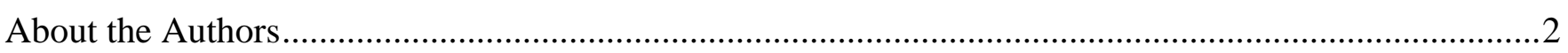

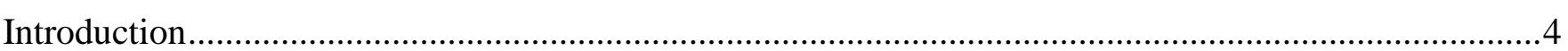

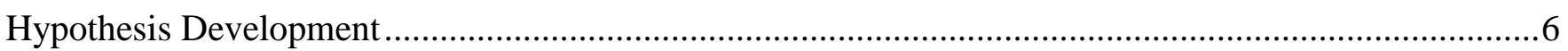

Theoretical Foundations: Service-Dominant Logic in IT Management ............................................6

IS-Business Alignment as a Mechanism in the ITSM Capability-Effectiveness Relationship ..............8

Strategic Conservativeness Strengthens the ITSM Capability-Effectiveness Relationship .................11

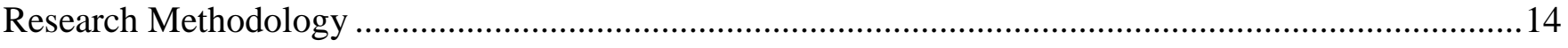

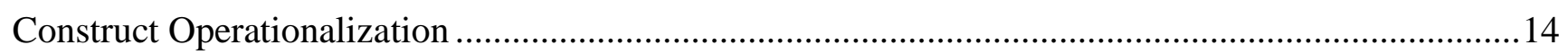

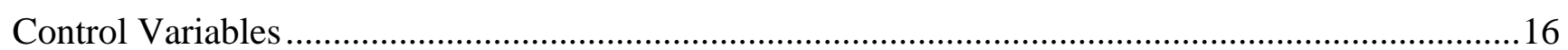

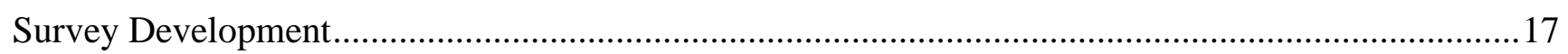

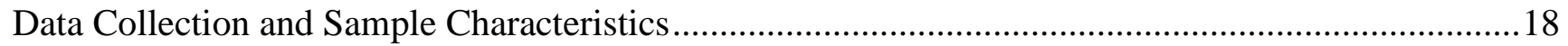

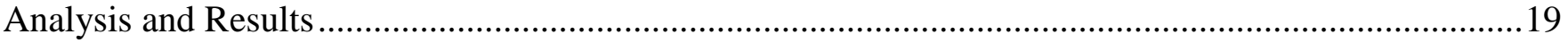

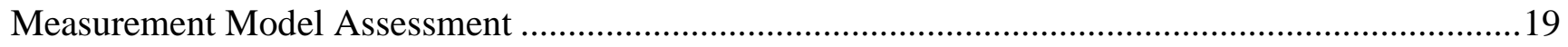

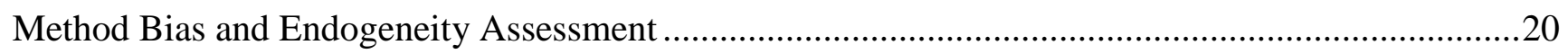

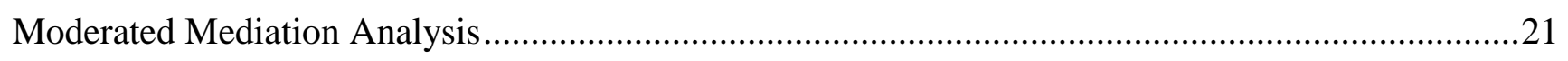

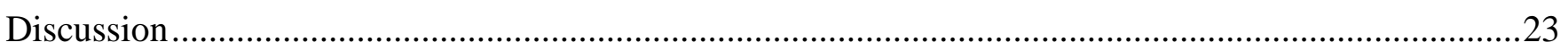

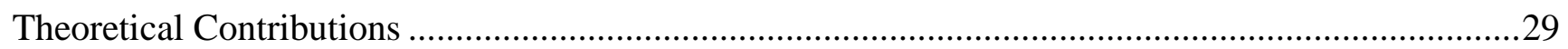

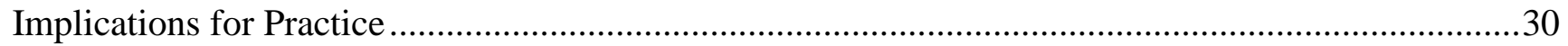

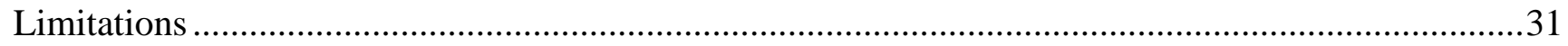

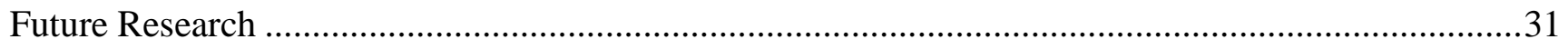

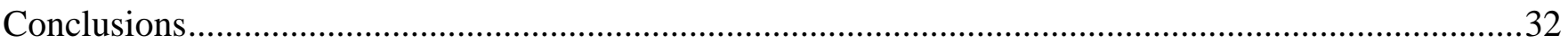

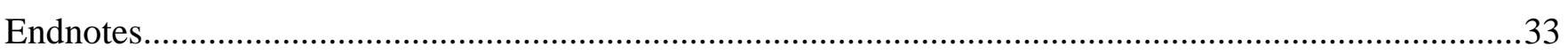

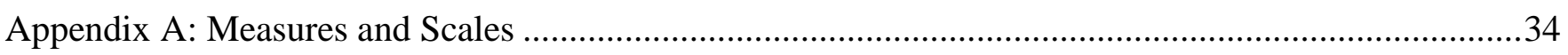

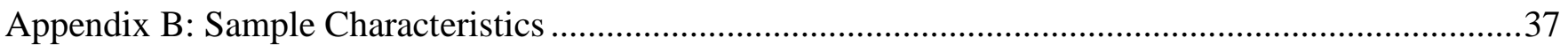

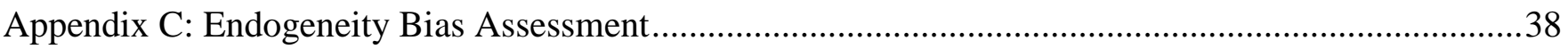

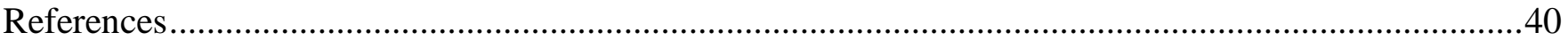

Supplement A: Review of the IT Service Management Literature …..............................................44

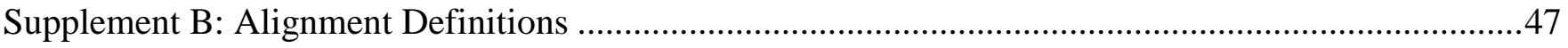

Supplement C: Maturity Scale and Attribute Descriptors ….........................................................51

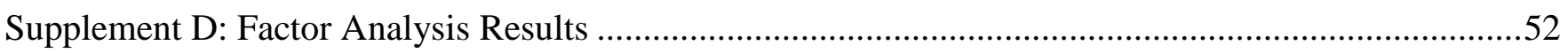

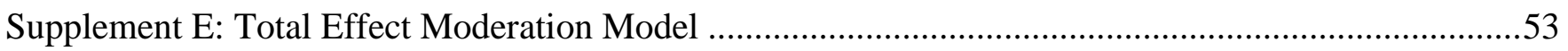

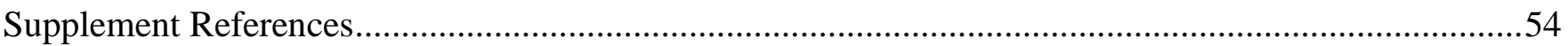




\section{Effectiveness of IT Service Management Capability: Value Co-Creation and Value Facilitation Mechanisms}

\section{INTRODUCTION}

The orientation toward services has become the dominant approach to manage information systems (IS) functions at organizations worldwide. Information technology service management (ITSM) refers to a principle that uses widely accepted "good practices" for organizing processes and people around customer-oriented services, rather than around tasks related to managing systems and physical infrastructures $[3,50]$. The ITIL reference model (formerly the IT Infrastructure Library) [11] is one prominent example of a collection of practices that have been gathered over the decades by various interest groups and compiled into a coherent framework, which has become the most widely accepted approach to ITSM in the world according to its proprietor's reports. ${ }^{1}$ The practices in distinct domains of the IT service lifecycle are of importance to any business since the assets utilized to provide IT services typically account for the majority of the total cost of IT ownership [23].

While ITSM practices come under scrutiny for every company that wishes to increase the effectiveness of the IS function, the concrete value-creation potential of ITSM is not without controversy in research and practice. Recently, for example, questions have been raised regarding whether the stability-oriented ITSM routines from the 1980s are compatible with the strategic IT innovation and agility required in today's fast-moving and digitally transforming world [8]. A sound understanding of ITSM effects is critical for rationalizing process improvement efforts in IS functions since establishing ITSM is arduous and costly [50].

The academic literature is only beginning to empirically study and theoretically explain the effects of ITSM on organizational IS effectiveness outcomes. We conducted a systematic review of the prior empirical literature on ITSM (reported in Online Supplement A) and found two major gaps. (1) Prior empirical ITSM literature is limited in that it does not measure ITSM capability across different IT service lifecycle phases, and (2) it lacks a coherent theoretical framework to explain ITSM effects on 
organizations. Although prior studies provide evidence for various desirable outcomes related to ITSM implementations [36], we still lack insight on how (i.e., through which mechanisms) and when (i.e., contingent upon which contextual conditions) ITSM creates the greatest value to organizations.

Addressing these gaps, this study draws on the service-dominant logic $[5,68,69]$ as a theoretical lens that views the assimilation of ITSM practices as an act of building specialized capabilities needed to create value between internal service providers (IS functions) and customers (business units). Moreover, ITSM capability emerges from routinized types of behavior [5] that cover different phases of the IT service lifecycle of the internal business-IS service relationship [17, 20, 54]. Its potential value is captured in use and is expressed in organizational IS effectiveness outcomes [15, 33].

Our theoretical development regarding the ITSM capability effects on IS effectiveness leads to two hypotheses. Recognizing the necessity of mutual alignment in interactional value co-creation [21, 25, 69], we first develop the hypothesis that ITSM capability enhances IS effectiveness through the mechanism of IS-business alignment. Second, given the eminent role of the strategic context for value creation in service relationships $[14,16,51]$, we hypothesize that the strength of the ITSM capabilityeffectiveness relationship is contingent upon organizational IS strategic conservativeness (i.e., the degree to which the organization follows a safe and stable approach to new IS initiatives).

Our firm-level data from a survey of ITSM key informants at 256 organizations in Europe provide support for these hypotheses. First, the majority of the ITSM capability effects on IS effectiveness (64\%) arise via the mechanism of IS-business alignment, with all other variables held constant at mean values. We argue that the finding that there are still multiple ways in which ITSM capability affects IS effectiveness provides evidence for a co-occurrence of value co-creation and value facilitation mechanisms [29, 30, 32] in internal IT service relationships. Second, IS strategic conservativeness strengthens the direct effects of ITSM capability on IS effectiveness but not the effects arising through the IS-business alignment mechanism. The ITSM capability-effectiveness relationship is stronger for more conservative and weaker for more innovative IS functions. This suggests that ITSM capability 
carries greater potential value for organizations that follow a more exploitative and stable approach to organizational learning. Jointly, our findings contribute a novel understanding to the literature of the value co-creation and value facilitation mechanisms by which ITSM capability affects IS effectiveness in internal IT service relationships and the contextual strategy attributes that influence the balance between these two distinct value-creation mechanisms.

\section{HYPOTHESIS DEVELOPMENT}

This section reviews the service-dominant logic in IT services that guides this research and develops the two central hypotheses being tested. Table 1 provides an overview of the key constructs.

Table 1. Construct Definitions.

\begin{tabular}{|l|l|l|}
\hline \multicolumn{1}{|c|}{ Construct } & \multicolumn{1}{c|}{ Definition } & \multicolumn{1}{c|}{ Key References } \\
\hline $\begin{array}{l}\text { IT service management } \\
\text { capability (ITSM capability) }\end{array}$ & $\begin{array}{l}\text { Routinized types of behavior in the use of assets to provide IT } \\
\text { services to a customer organization covering all phases of the IT } \\
\text { service lifecycle }\end{array}$ & {$[5,11]$} \\
\hline IS effectiveness (effectiveness) & The perceived value and business contributions of the IS function & {$[12,15,33]$} \\
\hline $\begin{array}{l}\text { IS-business alignment } \\
\text { (alignment) }\end{array}$ & $\begin{array}{l}\text { The degree to which the IS function supports the needs, demands, } \\
\text { and goals of an organization's business functions }\end{array}$ & {$[13,26,53,67]$} \\
\hline $\begin{array}{l}\text { IS strategic conservativeness } \\
\text { (conservativeness) }\end{array}$ & $\begin{array}{l}\text { The degree to which the organization follows a stable approach to } \\
\text { IS initiatives by carefully examining IS innovations once they have } \\
\text { been proven in their industry }\end{array}$ & {$[16,47]$} \\
\hline
\end{tabular}

\section{Theoretical Foundations: Service-Dominant Logic in IT Management}

Information systems research has shown great interest in the service-dominant logic [e.g., 29, 68, 69] in different strands of research, including IT management [3]. While service research in IT management has primarily focused on IT value creation in external customer/provider relationships, such as in IT sourcing, business alliances, and ecosystems [e.g., 34, 61], some authors have also begun to use a service-dominant perspective to theorize on internal IT service provision [e.g., 48].

In contrast to a goods-dominant logic that focuses on the exchange of units of output produced from input factors, a foundational premise of the service-dominant logic is that the fundamental basis of exchange is service. Services are defined as "the application of specialized knowledge and skills [operant resources] through deeds, processes and performances for the benefit of another entity or the entity itself' [68, p. 2]. Operant resources are specialized capabilities that act on operand resources (i.e., 
primary input factors) to produce intended effects [43]. Consequently, we can understand IT services as the application of specialized capabilities on IT assets (i.e., operand IT resources, such as hardware infrastructure, software applications, human skills, and knowledge). Specialized capabilities define how service activities use the operand resources, and they structure the interaction between the provider and the customer [31].

Specialized capabilities are constituted in routinized types of behavior, that is everyday practices, which are recurrent and ongoing and can involve a range of activities, bodies, and artifacts [5]. In this research, the specialized capability of an IT service provider (ITSM capability) is defined as routinized types of behavior in the use of assets to provide IT services to a customer organization. For the case of ITSM, these everyday practices have been codified as ostensive versions in reference models that describe concrete ITSM practices [37]. Examples for these reference models are ITIL, the Microsoft Operations Framework, the ISO/IEC 20000 standard, and the Capability Maturity Model Integration for Services. The practices in ITSM orchestrate the interaction of the IS function across different phases of the lifecycle of an IT service, including service planning, service transition, and service operation [17, 20, 54]. Service planning involves detecting customer needs and, with the customers, jointly translating those needs into service concepts [17]. Service transition encompasses the implementation of services by establishing the operative potential (i.e., resources and capabilities) for service delivery on the provider and customer sides [54]. Service delivery includes all provider and customer activities during service consumption, including service support [59], and service recovery [20].

In a service-dominant logic, value is created in use [68]; that is, value is created exclusively in the sphere of the customer to which the provider may or may not have access [32]. The service-dominant logic further recognizes that value is idiosyncratic, experiential, and laden with meaning [69], making it a multi-faceted, context-dependent, and difficult-to-measure concept [31]. There is an ongoing debate regarding how value can be conceptualized for the purpose of linking the service-dominant logic to empirical findings [10], and prior authors have used different proxies for value when measuring 
outcomes of service characteristics and capabilities. For example, for a study of firm service characteristics in consumer industries, Miles et al. [51] used the customer's satisfaction with a specific facility as a proxy for value in use, arguing that a customer who values the service being offered will also be more satisfied. Focusing on customer satisfaction parallels arguments in the IS service literature, that value is determined by the beneficiaries of the service process and their experiences [48].

Given that our focus is not the value in use of an individual service but of an entire portfolio of IT services provided by an IS function, we propose that the value in use in internal IT service relationships can be best captured by IS effectiveness $[12,33]$. The term IS effectiveness refers to the perceived value and business contributions of the IS function, including multiple facets, such as business satisfaction, quality of services, and business process support [33]. Increasing IS effectiveness has since been a central goal of IS management, which justifies the inclusion of this variable in this study of the effects of ITSM practices. Further, IS effectiveness is idiosyncratic to an organization and is experiential since it is reflected in day-to-day business operations. Hence, the IS effectiveness construct is appropriate to approximate the value in use created from ITSM capability.

\section{IS-Business Alignment as a Mechanism in the ITSM Capability-Effectiveness Relationship}

Because customers create service value in use, service researchers consider the production of value to which a service provider's operant resources contribute to be a co-creation mechanism [68]. Co-creation represents an interactional value formation process between a service provider and service customer that consists of aligning a provider's resources to those of a customer. For this research, we build on the definition of IS-business alignment as the degree to which the IS function supports the needs, demands, and goals of an organization's business functions [67].

The ability to understand what the customer needs is critical to the provider's learning about how to orchestrate interactions with the customer [31]. Provider-customer alignment is a critical requirement because the interaction between service providers and customers does not result per se in value cocreation. Quite the contrary, a service provider's customer interactions may well result in the destruction 
of value if the provider's activities do not match the customer's situational demand [32]. The value creation in the customer sphere thus relies on whether the provider's specialized capabilities align the service provider's activities with the service customer's needs [21]. Only if there is a consensus regarding the procedures and the understanding that inform a specific interaction does an interaction result in value co-creation [21].

Prior service research in IS has explored the role of two types of alignment in value co-creation: alignment of goals and alignment of resources. Lempinen and Rajala [48] explored the value-creation process at two internal IT service providers and found the mutual alignment of goals and interests among stakeholders to be key factors that influence perceived value outcomes. Although "alignment has not [yet] been formally evaluated under the rubric of service science," Tallon [65, p. 221] considered the internal alignment of business and IT goals when studying service orientation and value co-creation in US banking. In the context of business-to-business (B2B) software vendor alliances, Sarker et al. [61] proposed that value co-creation requires alignment of complementary and supplementary resources between the involved parties. While these prior studies motivate the need for considering alignment in a service-dominant logic, how this alignment can be conceptualized in internal IT service relationships remains underexplored.

We pose that alignment of goals and resources in internal IT service relationships can be best understood by drawing on the well-established notion of intellectual and operational cross-domain alignment between the IS function and business units (termed IS-business alignment herein; see Online Supplement B for a systematization of alignment definitions in IS). The IS-business alignment construct used in this research (Table 1) includes aspects of both intellectual alignment (i.e., the alignment of missions, objectives, and plans of the IS strategy with the business strategy) and operational alignment (i.e., the alignment of business and IT infrastructure covering procedures, skills, and resources in day-to-day operations) $[26,70] .{ }^{2}$ Prior alignment research has found consistent evidence that IS-business alignment is associated with various organizational performance outcomes [13], including IS effectiveness [12]. 
Organizations that successfully align their IT service provider strategy and operations with business needs will outperform those that do not because alignment leads to more focused and strategic use of their operand and operant IT resources, which, in turn, leads to increased IS effectiveness [12].

Given the service-dominant premise that specialized capabilities structure the interaction between the provider and customer [31] and the notion that this interaction can enable the alignment of goals and resources that are necessary for value co-creation [21, 32], we posit that ITSM capability enhances IS effectiveness specifically because it fosters IS-business alignment. In fact, the structuring of interactions is highly apparent for the case of ITSM capability. Many of the everyday practices defined by ITSM reference models are ultimately directed at fostering IS-business interaction with the goal of establishing cross-domain alignment within organizations. For example, service planning practices, such as demand management, business relationship management, and service level management, maintain the linkages to the business organization to understand the business needs and translate these into adequate IT service levels [11, I, p. 36]. Service transition practices, such as release and deployment management, ensure that new or modified IT services meet the expectations of the business [11, III, p. 43)]. Service operation practices, such as incident management, change management, and request fulfillment, aim to respond to user needs and ensure a smooth user experience [11, IV, p. 35]. In other words, the practices reflecting ITSM capability incorporate important interaction routines that have the goal to ensure continuous IS-business alignment.

In turn, IS-business alignment is a prerequisite for IS effectiveness, or from a service-dominant stance, the quality of interactions is fundamental for customer value creation [32]. However, ITSM capability is unlikely to affect IS effectiveness directly since in a service-dominant logic, the customer is always an operant resource, and value is exclusively the result of co-creation $[68,69]$. Therefore, a specialized capability, such as ITSM capability, does not possess value to an organization unless it is applied in an interactional value formation process through alignment with business functions. Altogether, we 
therefore posit that an organization's IS-business alignment mediates the effects of ITSM capability on IS effectiveness. We hypothesize the following:

Hypothesis 1: ITSM capability enhances IS effectiveness because it improves IS-business alignment.

\section{Strategic Conservativeness Strengthens the ITSM Capability-Effectiveness Relationship}

The service-dominant logic emphasizes the fact that the generation and interpretation of value are inherently contextual [69]. This focus on context is consistent with arguments for more sensitivity to the influence of contextual variables in the broader management literature [41]. Chandler and Vargo [14, p. 40] defined a particular context "as a set of unique actors with unique reciprocal links among them." The context frames the market in which service, the fundamental basis of exchange, takes place [14]. In the case of internal IT service provision, the context can be best understood as the organizational framework in which internal IT providers (the IS function) and customers (the business) interact. Since value is determined by the customer, operand and operant resources may carry greater potential value in some contexts and lower potential value in other contexts [32]. Hence, the value in use of service resources largely becomes a function of the context in which they are embedded [14].

Although service-dominant logic remains tacit on specific variables that characterize the context of value creation, some service research has argued that strategy is one of the most fundamental variables to characterize different organizational contexts [51]. It is a basic premise of the strategy literature that success is contingent on a firm's match between its internal capabilities and the opportunities that are afforded by its external environment [16]. A firm's strategy is the unique result of its external environment and internal capabilities [52], including the specialized capabilities needed for effective service delivery.

While it stands to reason that specialized service capabilities need to match a service provider's strategy, prior service research has paid scant attention to the importance of the strategic context in scrutinizing the value-in-context of specialized capabilities [51]. Among the earliest attempts to link service research with competitive strategy is the service concept by Goldstein et al. [27], who emphasized the role of a 
business strategy for service design by building on Porter's [57] generic strategies. In a similar vein, Miles et al. [51] explored the role of competitive strategy in the relationship between firm service characteristics and customer satisfaction. These works in the marketing literature provide evidence for the importance of matching firm strategy and operational decisions when seeking to maximize customer satisfaction [51].

The emerging service literature in IS still lacks a discussion of strategy attributes in internal IT service contexts. However, prior IS research provides theoretical foundations to build on that conceptualize IS strategy as the counterpart of business strategy [16]. Based on a review of the IS strategy-related literature, Chen et al. [16] conceptualized IS strategy as "a shared view of the IS role within the organization" and proposed a typology of three IS strategic profiles: IS innovator, IS conservative, and undefined, whereas the latter denotes the absence of either of the first two profiles. This typology is grounded in the tradeoffs between exploration versus exploitation in the organizational learning literature [49]. It is also consistent with the distinction of Porter's [57] differentiation versus costleadership and the prospector versus defender business strategy profiles of the typology by Miles et al. [52]. The IT innovator seeks to be an industry leader by exploring, developing, and capitalizing on new IT services. In contrast, the IT conservative seeks a more stable approach and exploits new IT services only after careful scrutiny [16]. We focus on the relative tradeoffs between conservative (exploitative) versus innovative (explorative) IS strategy attributes and define IS strategic conservativeness as the degree to which the organization follows a stable approach to IS initiatives by carefully examining IS innovations once they have been proven in their industry.

Given the eminent role of the strategic context in service relationships, we propose that the IS strategic orientation is likely to play a moderating role in the relationship of ITSM capability and IS effectiveness. The service-dominant logic informs us that context affects the value in use of operant resources [14]. For the case of internal IT service provision, this means that ITSM capability has different value-creating potential, depending on the IS strategic context of the firm. In particular, the institutionalization of 
routinized types of behavior, such as those recommended by ITSM reference models, may carry higher potential value for those IT service providers that follow a more stable approach to innovation and exploit new IT services only after careful scrutiny [39], which defines the IS conservative [16].

Organizations with a conservative IS strategy are likely to benefit from routinizing the service management practices to a greater extent than those with an innovator IS strategy since these routines (operant resources) allow them to exploit their IT assets (the operand resources) in a better way. Better exploitation, in turn, creates greater potential value in the customer sphere. For example, ITSM frameworks demand adherence to standard routines with an increasing assimilation of their substantive practices to optimize the use of IT assets to improve service outcomes.

Innovation orientation, in contrast, is characterized by creating variation through experimenting and risktaking and thus must be buffered from a too-rigid formalization [7]. This implies that a relatively more innovative IS strategic orientation will lead to a certain devaluation of operant resources since the IS innovators primarily seek to build new resources for providing new IT services, rather than exploiting existing ones. As motivated at the outset, practitioners have recently questioned whether the highly formalized ITSM routines will suit organizations that need to provide IT in a highly agile and innovative manner [8]. Formalized routines may lead to inflexibility and hamper innovation, as Chen et al. [16, p. 248] proposed.

In summary, building on the notion that value creation is strongly context dependent and on the argument that the IS strategy captures key organizational context characteristics of internal IS providercustomer relationships, we hypothesize that the IS strategic orientation moderates the effect of ITSM capability on IS effectiveness. Specifically, the effect of ITSM capability on IS effectiveness will be stronger in conservative IS contexts and weaker in innovative contexts. We propose the following: Hypothesis 2: IS strategic conservativeness strengthens the positive effect of ITSM capability on IS effectiveness. 


\section{RESEARCH METHODOLOGY}

We conducted a survey among ITSM key informants by distributing survey invitations to the members of three European chapters of the IT Service Management Forum, an independent, worldwide, not-forprofit association of ITSM professionals. Practitioners engaged in professional organizations are typically interested in cross-organizational knowledge exchange and are therefore reasonably well positioned to serve as key informants for their respective organizations, as they are expected to be knowledgeable about the specific subject being researched and to be able to generalize beyond their own working environment [46]. Additionally, IT service management reference models are widely adopted in the European region [50], which makes ITSM experts from this region suitable as respondents.

\section{Construct Operationalization}

For the operationalization of the research constructs (Table 1), we built on prior literature and developed our own measures where necessary. In particular, given the shortcomings of prior research in measuring ITSM capability (Online Supplement A), we developed a scale for measuring ITSM capability as a second-order construct that considers distinct phases of the service lifecycle. All measures and scales are provided in Appendix A of this article.

To assess ITSM capability, we built on the 26 common ITSM practices popularized by ITIL. Our choice to use the nomenclature of ITIL was motivated by the pervasive usage of this reference model, its similarity to alternative ITSM reference models, and its comprehensibility to qualified ITSM professionals. Their maturity was assessed using the six-point Capability Maturity Model Integration (CMMI) scale with the scale anchors ranging from "none" to "optimized," which have also been used by prior IS research [e.g., 58] and are widely known in practice. To overcome measurement weaknesses of prior ITSM studies and to give full particulars for each of these maturity scale levels, we first reviewed four CMMI-based IT process reference models and identified attributes that jointly determine a level of ITSM practice maturity. Specific anchors were then derived for each of these attributes at each maturity level and compiled into a concise matrix. This maturity scale is provided in Online Supplement C. 
Since ITSM capability is a latent construct whose level is mirrored in the degree of maturity of multiple practices across different phases of the service lifecycle [17, 20, 54], we operationalized ITSM capability as a reflective second-order construct with three first-order dimensions: service planning capability, service transition capability, and service operation capability. ${ }^{3}$ Service planning capability refers to the practices that determine an IT service provider's overarching objectives, financing principles, service offerings, and the levels at which these will be provided. Service transition capability refers to the practices that ensure that newly planned or changed services are implemented correctly and function as planned. Service operation capability refers to the practices that manage the interactions with service users to restore or sustain the users' service experience in the day-to-day delivery of IT services [11].

The perceived effectiveness of the IS function (effectiveness) was modeled as a reflective construct that assesses efficiency, quality, business process effectiveness, user satisfaction, and strategic effectiveness of the IS function. These five items are consistent with prior studies that measured IS effectiveness [12] and IS functional performance [15], and they also match the five outcomes identified by our review of the empirical ITSM literature (Online Supplement A). The assessment relative to comparable organizations (or competitors) is widely applied to assess organizational performance variables [e.g., 72].

The level of IS-business alignment (alignment) was measured using the six items previously used by Tiwana and Konsynski [67], which assess the degree of alignment of an IS function with the activities, expectations, needs, demands, priorities, and objectives of the business. We opted for this direct measurement of IS-business alignment and against indirect measures to account for this construct's nomological role as a mediator in our model. Direct measures are commonly used when simultaneously testing theories about the antecedents and outcomes of IS-business alignment [18].

For the operationalization of the relative IS strategic conservativeness (conservativeness), we used two factors proposed by Chen et al. [16] that measure the shared view of being conservative versus 
innovative using five items that have been validated and used in other IS strategy research [47]. Due to our selective interest in the tradeoff between the conservative versus the innovator IS role, we used the scores of each factor and calculated the single-factor IS strategic conservativeness as the difference between the factor scores for IS conservatives and IS innovators.

\section{Control Variables}

We include five organizational-level and three individual-level controls as potentially confounding influences on IS effectiveness for either theoretical or methodological reasons (see Table 2).

\section{Table 2. Control Variables.}

\begin{tabular}{|l|l|l|}
\hline Controls & Operationalization & References \\
\hline Industry sector & $\begin{array}{l}\text { Categorical dummy for industry membership (International Standard } \\
\text { Industrial Classification) }\end{array}$ & {$[44]$} \\
\hline HQ location & Global region in which the company headquarters is located & {$[50]$} \\
\hline Client size & Log-transformed number of employees on the customer side & {$[28]$} \\
\hline Service orientation & $\begin{array}{l}\text { Two items related to the service orientation of the business sector and } \\
\text { product }\end{array}$ & {$[65,71]$} \\
\hline Regulatory exposure & $\begin{array}{l}\text { Two items related to a firm's need to comply with statutory requirements } \\
\text { and other industry requirements }\end{array}$ & {$[1]$} \\
\hline Vertical position & Management level of the rater's job position from executive to staff level & {$[55,63]$} \\
\hline Horizontal position & Rater affiliation with the business side or IT side of the organization & {$[55,63]$} \\
\hline Job tenure & Time of job tenure in years & {$[55,63]$} \\
\hline
\end{tabular}

The industry sector (operationalized categorically on the basis of International Standard Industrial Classification segments) potentially influences effectiveness because core determinants of IS effectiveness, such as IT penetration or product digitization, differ per industry [44]. Our data consider six specific industry sectors (finance, information and communication, manufacturing, professional and public services, hospitality and mobility, and utilities and construction). The headquarters location, which we operationalize by three global regions (Americas; Asia Pacific; and Europe, the Middle East, and Africa [reference category]), potentially influences effectiveness because organizations may be subject to region-specific environmental constraints [50]. Client size, operationalized as the logtransformed number of client-side employees, might influence effectiveness since larger firms may have richer IS resources, higher expertise, and greater economies of scale [28]. The level of service orientation of the company, operationalized with two items related to the service orientation of the 
sector and the product [71], might influence effectiveness outcomes since service businesses may also have a greater internal focus on value co-creation between business and IS functions [65]. Regulatory exposure, measured by two self-developed items related to a firm's needs to comply with statutory requirements and laws as well as other requirements, such as industry standards, may influence IS effectiveness since compliance activities bind IT resources that could otherwise contribute to IS effectiveness outcomes [1].

On the individual level, it stands to reason for this study on effectiveness of ITSM capability to give special consideration to potential response biases due to the individual job position of the respondent. We consider the horizontal position (i.e., the business or IS function side, operationalized by a binary dummy), the vertical position, ranging between executive and staff level (operationalized by a five-point measure), and the job tenure (operationalized with ordinal items that capture time ranges of employment in the company) to be controls to account for these biases. The IS function respondents, for example, may rate more favorably on certain ITSM practices and outcomes, which can lead to systematic parameter inflations. These are controlled by the horizontal position variable [55, 63].

\section{Survey Development}

We took several measures in the online survey design to prevent systematic biases. First, the overall survey design was guided by the principles of a cognitive approach [40], which focuses on the mental processing and understanding of these constructs by the survey respondents, in our case, the targeted ITSM professionals. Item stems and surrounding explanations are often more extensive in cognitionaware questionnaire designs, while the items can be shorter and simpler [e.g., 26]. Second, we guaranteed the respondent's anonymity and provided incentives for sufficient care in rating by presenting benchmark scores to the respondent at the end of the survey. Third, we separated predictor and criterion variables in our survey design through webpages. Fourth, the independent and dependent variables used different scale anchors. 
The survey was provided in the English and German languages, with several steps taken to ensure reliability, validity, and language consistency. An initial version was reviewed by three experienced ITSM experts, who, among other details, emphasized the necessity to give full particulars of the maturity scale to enable reliable assessment through survey participants. After our development of the maturity scale (Online Supplement C), this scale was discussed in depth in a focus group with three ITSM experts at a major auditing firm, who suggested several minor revisions but asserted face validity and fitness for the practical purpose of self-assessment. Finally, we conducted a survey pretest with 23 practitioners and fellow researchers who had prior ITSM experience from at least one organization and asked this group for comments. The pretest yielded acceptable reliability values $(\alpha>.8)$ for all constructs and only led to minor changes of wording and inclusion of additional explanatory texts in the survey. Post-hoc unpaired t-tests on all questionnaire items showed no systematic bias between the two different language versions.

\section{Data Collection and Sample Characteristics}

In late 2013 and early 2014, invitations to our online survey were included in email newsletters to all of the approximately 6,000 members of three national chapters of the IT Service Management Forum in Germany, Denmark, and Switzerland. From this group, 405 members provided survey responses, 41 of which were incomplete or invalid and were thus discarded. Of the 364 valid responses, 108 (30\%) referred to external service providers, so that, given our focus on internal IS functions, we included only the remaining 256 responses in the analysis. This cross-sectional sample is free from duplicates and includes organizations from finance and insurance (19.5\%), manufacturing (21.1\%), information and communication (6.6\%), and other industries (see Table B1 in Appendix B for detailed sample characteristics). The surveyed organizations were reported to have a median of 3,000 employees overall and a median of 100 employees at the internal IS function. The majority of respondents $(218 ; 85.2 \%)$ reported affiliation with the IS function, while 38 (14.8\%) indicated affiliation with the business side of the organization. ${ }^{4}$ Respondents reported an average of 5.9 years of tenure in their current roles at diverse 
management levels (Appendix B, Table B1). Moreover, 70\% reported possessing a certified ITSM qualification at least at the foundation level. ${ }^{5}$

\section{ANALYSIS AND RESULTS \\ Measurement Model Assessment}

We conducted an exploratory factor analysis (EFA) with oblique rotation (reported in Table D1 in Online Supplement D). Tabachnick and Fidell [64, p. 646] advocate using oblique rotation when some oblique-rotated factors exhibit high overlap in variance and propose a shared variance threshold of $10 \%$. In line with our theoretical conceptualization, three correlations exceed the associated factor correlation threshold of .32 (see Table 3). First, the causal effect of IS-business alignment on IS effectiveness is well established due to a more focused and strategic use of IT resources [12]. Second, we expect a strong causal link between ITSM capability and IS-business alignment owing to the theoretical argumentation that specialized capabilities structure the interaction between the service provider and customer [31] and that this interaction can enable the alignment of goals and resources that are necessary for service value co-creation $[21,32]$. Third, owning to the theoretical conceptualization of ITSM capability as a service provider's specialized capabilities that support a customer's creation of value in use, which is grounded in service-dominant logic [68], we expect a strong correlation between ITSM capability and IS effectiveness.

Velicer's minimum average partial test, the achieved sample-size-adjusted Bayesian information criterion, and the substantial variance explained by the individual factors support our theorized choice of nine first-order factors (including controls). Our EFA (Table D1 in Online Supplement D) reports this nine-factor solution, including as factors all first-order constructs of our theoretical conceptualization (Table 1) and multi-item controls (Table 2). The oblique-rotated items exhibit acceptable factor loadings of above .45 and negligible cross-loadings of below .32 , which asserts the discriminant validity of the constructs [64, p. 649]. 
Acceptable scale alphas $(>.7)$ provide assurance that the scales have sufficient convergent validity to measure all model constructs (Table 3). Given the presence of high factor correlations, we calculated variance inflation factors (VIFs) for all independent variables and interaction terms in the subsequent models to rule out multicollinearity issues (based on the regression results below). Maximum VIF scores take on values of 2.58 (effectiveness) and 1.03 (alignment), which are below the cutoff of 5.0.

Table 3. Construct Correlations and Psychometric Properties.

\begin{tabular}{|c|c|c|c|c|c|c|c|c|c|c|c|c|c|}
\hline & $M$ & $S D$ & $\#$ & Alpha & $\begin{array}{c}\text { ITSM } \\
\text { capability }\end{array}$ & $\begin{array}{c}\text { Effective- } \\
\text { ness }\end{array}$ & $\begin{array}{c}\text { Align- } \\
\text { ment }\end{array}$ & $\begin{array}{c}\text { Conserva- } \\
\text { tiveness }\end{array}$ & $\begin{array}{c}\text { Client } \\
\text { size }\end{array}$ & $\begin{array}{c}\text { Service } \\
\text { orientation }\end{array}$ & $\begin{array}{c}\text { Regulatory } \\
\text { exposure }\end{array}$ & $\begin{array}{l}\text { Horizontal } \\
\text { position }\end{array}$ & $\begin{array}{l}\text { Vertical } \\
\text { position }\end{array}$ \\
\hline $\begin{array}{l}\text { ITSM capability } \\
\left(2^{n d}\right)\end{array}$ & 3.0 & 1.4 & 14 & .83 & & & & & & & & & \\
\hline \begin{tabular}{|l|} 
Planning \\
capability $\left(1^{s t}\right)$
\end{tabular} & 2.8 & 1.3 & 6 & .91 & & & & & & & & & \\
\hline $\begin{array}{l}\text { Transition } \\
\text { capability }\left(1^{\text {st }}\right)\end{array}$ & 2.9 & 1.3 & 3 & .87 & & & & & & & & & \\
\hline \begin{tabular}{|l|} 
Operation \\
capability $\left(1^{\text {st }}\right)$
\end{tabular} & 3.4 & 1.4 & 5 & .88 & & & & & & & & & \\
\hline Effectiveness & 4.3 & 1.4 & 5 & .92 & $.45^{*}$ & & & & & & & & \\
\hline Alignment & 4.4 & 1.4 & 6 & .94 & $.46^{*}$ & $.72 *$ & & & & & & & \\
\hline $\begin{array}{l}\text { Conservativeness } \\
\text { (dif) }\end{array}$ & - & - & 5 & - & \multirow{3}{*}{-.11} & \multirow{3}{*}{$-.16^{*}$} & \multirow{3}{*}{$-.13^{+}$} & & & & & & \\
\hline Innovator $\left(1^{s t}\right)$ & 3.8 & 1.9 & 3 & .87 & & & & & & & & & \\
\hline Conservative $\left(1^{\text {st }}\right)$ & 4.7 & 1.6 & 2 & .73 & & & & & & & & & \\
\hline Client size & 3.4 & 1.0 & 1 & - & $.19 *$ & $.13^{+}$ & .09 & -.08 & & & & & \\
\hline \begin{tabular}{|l} 
Service \\
orientation
\end{tabular} & 4.9 & 2.2 & 2 & .81 & -.03 & .03 & .06 & -.11 & -.03 & & & & \\
\hline \begin{tabular}{|l|}
$\begin{array}{l}\text { Regulatory } \\
\text { exposure }\end{array}$ \\
\end{tabular} & 5.2 & 1.7 & 2 & .70 & .11 & $.16^{*}$ & $.18 *$ & .08 & $.20 *$ & $.21 *$ & & & \\
\hline \begin{tabular}{|l} 
Horizontal \\
position $^{d}$
\end{tabular} & - & - & - & - & -.03 & $-.20 *$ & $-.18 *$ & .02 & $-.22 *$ & -.09 & $-.12^{+}$ & & \\
\hline Vertical position & 2.8 & 0.9 & 1 & - & .01 & -.01 & -.02 & -.00 & $.15^{+}$ & -.11 & .05 & .08 & \\
\hline Job tenure & 5.2 & 1.8 & 1 & - & $.18^{*}$ & $.24 *$ & $.18^{*}$ & -.06 & $.27 *$ & .04 & .09 & -.04 & .12 \\
\hline
\end{tabular}

$1^{\text {st }}=$ first level construct; $2^{\text {nd }}=$ second level construct; dif $=$ differential score; $d=$ dummy variable ${ }^{+} p<.05 ; * p<.01$

\section{Method Bias and Endogeneity Assessment}

Beyond the preventative measures taken in our survey design, we assessed our data post-hoc for potential biases that may occur in study designs in which antecedent and outcome variables are being assessed by the same raters. First, we acquired additional ratings on the dependent variables (alignment and effectiveness) from matched-pair respondents with opposing horizontal job positions at 22 organizations from the original sample. ${ }^{6}$ The median interrater agreement scores $r_{w g}$ [38] for these 22 organizations were .98 for alignment and .96 for effectiveness, suggesting high interrater agreement. The $T$ indexes, patterned after Cohen's kappa for which we defined agreement as no or a one-point 
discrepancy in ratings, resulted in values of .86 for alignment and .67 for effectiveness, thus asserting acceptable-to-high interrater agreement between business and IS function respondents. Second, we assessed common variance using Harman's one-factor test [56]. This test showed that the first factor of an EFA of all model indicators accounted for $13 \%$ (i.e., less than the majority) of the total variance.

To assess endogeneity in our model predictor, we conducted several econometric analyses and diagnostics, as summarized in Appendix C. These analyses provide no evidence for endogeneity and hence suggest that the use of case-wise ordinary least squares (OLS) regression for our hypothesis tests is appropriate.

\section{Moderated Mediation Analysis}

To test H1, stating that ITSM capability enhances IS effectiveness because it improves IS-business alignment, we used a causal steps procedure and calculated the Sobel mediation test statistic [4]. Table 4 reports the standardized betas.

Table 4. Ordinary Least Squares Regression Results.

\begin{tabular}{|c|c|c|c|c|c|c|}
\hline Model: & $\begin{array}{l}\text { A1 } \\
\text { Main }\end{array}$ & $\begin{array}{l}\text { A2 } \\
\text { Moderation }\end{array}$ & $\begin{array}{l}\text { E1 } \\
\text { Controls }\end{array}$ & $\begin{array}{l}\text { E2 } \\
\text { Main }\end{array}$ & $\begin{array}{l}\text { E3 } \\
\text { Mediation }\end{array}$ & $\begin{array}{l}\text { E4 } \\
\text { Direct effect } \\
\text { moderation }\end{array}$ \\
\hline Dependent variable: & Alignment & Alignment & Effectiveness & Effectiveness & Effectiveness & Effectiveness \\
\hline \multicolumn{7}{|l|}{$\overline{\text { Controls }}$} \\
\hline Industry finance & & & $\begin{array}{r}-.830^{*} \\
(-2.086)\end{array}$ & $\begin{array}{c}-.793^{*} \\
(-2.205)\end{array}$ & $\begin{array}{r}-.401 \\
(-1.408)\end{array}$ & $\begin{array}{r}-.424 \\
(-1.486)\end{array}$ \\
\hline $\begin{array}{l}\text { Industry information } \\
\& \text { communication }\end{array}$ & & & $\begin{array}{r}.049 \\
(0.186)\end{array}$ & $\begin{array}{r}.062 \\
(0.256)\end{array}$ & $\begin{array}{r}-.048 \\
(-0.254)\end{array}$ & $\begin{array}{r}-.067 \\
(-0.358)\end{array}$ \\
\hline $\begin{array}{l}\text { Industry } \\
\text { manufacturing }\end{array}$ & & & $\begin{array}{r}-.090 \\
(-0.518)\end{array}$ & $\begin{array}{r}.004 \\
(0.023)\end{array}$ & $\begin{array}{r}.085 \\
(0.683)\end{array}$ & $\begin{array}{r}.102 \\
(0.826)\end{array}$ \\
\hline $\begin{array}{l}\text { Industry professional } \\
\text { \& public Services }\end{array}$ & & & $\begin{array}{r}-.413^{*} \\
(-2.131)\end{array}$ & $\begin{array}{r}-0.215 \\
(-1.215)\end{array}$ & $\begin{array}{r}-.063 \\
(-0.447)\end{array}$ & $\begin{array}{r}-.004 \\
(-0.027)\end{array}$ \\
\hline $\begin{array}{l}\text { Industry hospitality } \\
\& \text { mobility }\end{array}$ & & & $\begin{array}{r}.420 \\
(1.783) \\
\end{array}$ & $\begin{array}{r}.309 \\
(1.448) \\
\end{array}$ & $\begin{array}{r}.160 \\
(0.948) \\
\end{array}$ & $\begin{array}{r}.144 \\
(0.859) \\
\end{array}$ \\
\hline $\begin{array}{l}\text { Industry utilities \& } \\
\text { construction }\end{array}$ & & & $\begin{array}{l}-.234^{* * *} \\
(-2.827)\end{array}$ & $\begin{array}{r}-.148 \\
(-1.959)\end{array}$ & $\begin{array}{r}-.060 \\
(-0.991)\end{array}$ & $\begin{array}{r}-.051 \\
(-0.852)\end{array}$ \\
\hline HQ Americas & & & $\begin{array}{r}-.042 \\
(-0.274)\end{array}$ & $\begin{array}{r}.037 \\
(0.273)\end{array}$ & $\begin{array}{r}.043 \\
(0.378) \\
\end{array}$ & $\begin{array}{r}.042 \\
(0.338)\end{array}$ \\
\hline HQ Asia Pacific & & & $\begin{array}{r}-.122 \\
(-1.620)\end{array}$ & $\begin{array}{r}-.226 \\
(-1.395)\end{array}$ & $\begin{array}{r}-.184 \\
(-1.474)\end{array}$ & $\begin{array}{r}-.175 \\
(-1.336) \\
\end{array}$ \\
\hline Client size & & & $\begin{array}{r}-.045 \\
(-0.470) \\
\end{array}$ & $\begin{array}{r}-.130 \\
(-1.483) \\
\end{array}$ & $\begin{array}{r}-.068 \\
(-0.984) \\
\end{array}$ & $\begin{array}{r}-.051 \\
(-0.734) \\
\end{array}$ \\
\hline Service orientation & & & $\begin{array}{r}.004 \\
(0.073)\end{array}$ & $\begin{array}{r}.020 \\
(0.389)\end{array}$ & $\begin{array}{r}.012 \\
(0.301)\end{array}$ & $\begin{array}{r}.004 \\
(0.090)\end{array}$ \\
\hline Regulatory exposure & & & $\begin{array}{l}.404^{* *} \\
(2.663)\end{array}$ & $\begin{array}{r}.157^{*} \\
(2.484)\end{array}$ & $\begin{array}{r}.066 \\
(1.311)\end{array}$ & $\begin{array}{r}.073 \\
(1.452)\end{array}$ \\
\hline Horizontal position & & & $\begin{array}{c}-.441^{* *} \\
(-2.870)\end{array}$ & $\begin{array}{r}-0.518^{* * *} \\
(-3.427)\end{array}$ & $\begin{array}{r}-.476 \\
(-1.935)\end{array}$ & $\begin{array}{r}-.236 \\
(-1.944)\end{array}$ \\
\hline
\end{tabular}




\begin{tabular}{|c|c|c|c|c|c|c|}
\hline Model: & $\begin{array}{l}\text { A1 } \\
\text { Main }\end{array}$ & $\begin{array}{l}\text { A2 } \\
\text { Moderation }\end{array}$ & $\begin{array}{l}\text { E1 } \\
\text { Controls }\end{array}$ & $\begin{array}{l}\text { E2 } \\
\text { Main }\end{array}$ & $\begin{array}{l}\text { E3 } \\
\text { Mediation }\end{array}$ & $\begin{array}{l}\mathrm{E} 4 \\
\text { Direct effect } \\
\text { moderation }\end{array}$ \\
\hline Dependent variable: & Alignment & Alignment & Effectiveness & Effectiveness & Effectiveness & Effectiveness \\
\hline Vertical position & & & $\begin{array}{r}-.051 \\
(-0.715)\end{array}$ & $\begin{array}{r}-.073 \\
(-0.558)\end{array}$ & $\begin{array}{r}-.026 \\
(-0.498)\end{array}$ & $\begin{array}{r}-.019 \\
(-0.277)\end{array}$ \\
\hline Job tenure & & & $\begin{array}{l}.133^{* * * *} \\
(3.414)\end{array}$ & $\begin{array}{r}.110^{* * *} \\
(2.953)\end{array}$ & $\begin{array}{r}.077^{*} \\
(2.383) \\
\end{array}$ & $\begin{array}{r}.140^{*} \\
(2.153) \\
\end{array}$ \\
\hline \multicolumn{7}{|l|}{ Predictors } \\
\hline ITSM capability & $\begin{array}{l}.459^{* * * *} \\
(8.226)\end{array}$ & $\begin{array}{l}.462^{* * * *} \\
(8.214)\end{array}$ & & $\begin{array}{l}.414^{* * * *} \\
(7.188)\end{array}$ & $\begin{array}{l}.156^{* *} \\
(3.109)\end{array}$ & $\begin{array}{l}.169^{* * * *} \\
(3.361)\end{array}$ \\
\hline Alignment & & & & & $\begin{array}{r}.608^{* * * *} \\
(11.844) \\
\end{array}$ & $\begin{array}{r}.595^{* * * *} \\
(11.644) \\
\end{array}$ \\
\hline Conservativeness & & $\begin{array}{r}-.071 \\
(-1.275) \\
\end{array}$ & & & & $\begin{array}{r}-.065 \\
(-1.453) \\
\end{array}$ \\
\hline \multicolumn{7}{|l|}{ Interaction } \\
\hline $\begin{array}{l}\text { Conservativeness * } \\
\text { ITSM Capability } \\
\end{array}$ & & $.069(1.721)$ & & & & $\begin{array}{r}.059^{*} \\
(1.984) \\
\end{array}$ \\
\hline$\overline{R^{2}(F)}$ & $\begin{array}{r}.210 \\
\left(67.670^{* * *}\right) \\
\end{array}$ & $\begin{array}{r}.225 \\
\left(24.370^{* * *}\right) \\
\end{array}$ & $\begin{array}{r}.186 \\
\left(3.724^{* * *}\right) \\
\end{array}$ & $\begin{array}{r}.338 \\
\left(7.696^{* * *}\right) \\
\end{array}$ & $\begin{array}{r}.592 \\
\left(20.43^{* * *}\right) \\
\end{array}$ & $\begin{array}{r}.604 \\
\left(18.86^{* * *}\right) \\
\end{array}$ \\
\hline $\begin{array}{l}\Delta R^{2} \\
\text { (F-change) }\end{array}$ & & $\begin{array}{r}1.45 \% \\
(2.361)\end{array}$ & & $\begin{array}{r}15.13 \% \\
\left(51.673^{* * *}\right)\end{array}$ & $\begin{array}{r}25.41 \% \\
\left(140.276^{* * *}\right)\end{array}$ & $\begin{array}{r}1.12 \% \\
(3.164 \%)\end{array}$ \\
\hline
\end{tabular}

${ }^{*} p<.05 ;{ }^{* * *} p<.01 ;{ }^{* * *} p<.001$ (two-sided)

Without the mediator (alignment), ITSM capability has a significant, positive relationship with effectiveness ( $\beta=.414^{* * *}$, Model E2). Regressing on alignment as a dependent variable, ITSM capability has a significant, positive relationship with alignment $\left(\beta=.459^{* * *}\right.$, Model A1). Alignment has a significant, positive relationship with effectiveness $\left(\beta=.608^{* * *}\right.$, Model E3). In Model E3, we find a significant direct effect of ITSM capability on effectiveness $\left(\beta=.156^{* *}\right)$ that is substantially smaller than in Model E2 $\left(\beta=.414^{* * *}\right)$. Hence, the relationship of ITSM capability and effectiveness is partially mediated through alignment. The Sobel mediation test statistic's significant value of $6.514(p<.001)$ assures that the mediated effect is significant. Alternatives to the Sobel mediation test also yield statistical significance (Aroian test statistic: 6.498, $p<.001$; Goodman test statistic: $6.530, p<.001$ ). To test $\mathrm{H} 2$, stating that the positive effect of ITSM capability on effectiveness is moderated by conservativeness, we followed Edwards and Lambert's [22] guidelines for assessing a direct effect and first-stage moderation model that integrates mediation and moderation (see Table 5). We included the interaction term conservativeness * ITSM capability in Models A2 and E4. ${ }^{7}$ Including this interaction term in Model E4 explains a significant but modest additional variance $\left(\Delta R^{2}=1.12 \%\right)$. Model A2, in contrast, has an insignificant $\Delta R^{2}$. Following Edwards and Lambert's [22] bootstrapping procedure, we 
estimated simple paths, indirect and total effects for high and low levels of conservativeness (i.e., one standard deviation above and below the mean) with mean-centered variables in 1,000 bootstrapping samples. We used bias-corrected confidence intervals to test the effects and effect differences. As seen in Table 5, the direct and total effects show significant differences between high and low levels of conservativeness. Hence, the direct effect of ITSM capability on effectiveness is positively moderated by conservativeness. The more conservative a provider's IS strategic orientation is, the stronger the effect of its ITSM capability will be on IS effectiveness. It is worth noting that the results in Table 5 do not show significant differences in indirect effects between high and low levels of IS strategic conservativeness. That is, there is no support for the indirect effect being moderated by IS strategic conservativeness.

Table 5. Analysis of Simple Effects in the Direct Effect and First Stage Moderation Model.

\begin{tabular}{|l|c|c|c|c|c|}
\cline { 2 - 5 } \multicolumn{1}{c|}{} & \multicolumn{2}{c|}{ Stage } & \multicolumn{2}{c|}{ Effects } \\
\hline Moderator ${ }^{\text {a }}$ & $\begin{array}{l}\text { First } \\
(I T S M \rightarrow \text { Align })\end{array}$ & $\begin{array}{l}\text { Second } \\
\text { (Align } \rightarrow \text { Effect })\end{array}$ & $\begin{array}{l}\text { Direct } \\
(\text { ITSM } \rightarrow \text { Effect })\end{array}$ & $\begin{array}{l}\text { Indirect } \\
(\text { ITSM } \rightarrow \text { Align } \rightarrow \text { Effect })\end{array}$ & $\begin{array}{l}\text { Total } \\
(\text { direct }+ \text { indirect })\end{array}$ \\
\hline $\begin{array}{l}\text { High } \\
\text { conservativeness }\end{array}$ & $.586^{*}$ & $.589^{*}$ & $.270^{*}$ & $.345^{*}$ & $.615^{*}$ \\
\hline $\begin{array}{l}\text { Low } \\
\text { conservativeness }\end{array}$ & $.393^{*}$ & $.589^{*}$ & .093 & $.231^{*}$ & $.324^{*}$ \\
\hline Difference & .193 & .000 & $.178^{+}$ & .114 & $.292^{*}$ \\
\hline
\end{tabular}

a: high $=+1 S D$, low $=-1 S D ;{ }^{+} p<.05 ;{ }^{*} p<.01$

\section{DISCUSSION}

This study of the effectiveness of ITSM capability was motivated by the gaps in prior IT service research on how and when ITSM capability contributes to IS effectiveness outcomes. Rooted in a service-dominant logic, we theoretically developed the hypotheses that the relationship between ITSM capability and IS effectiveness is mediated by IS-business alignment (H1) and strengthened by IS strategic conservativeness $(\mathrm{H} 2)$. These two hypotheses were tested based on cross-sectional data from ITSM key informants in Europe working at companies across all major industries.

We found support for the hypothesis that ITSM capability enhances IS effectiveness because it improves IS-business alignment (H1). This result strengthens the view that ITSM capability orchestrates the 
interaction between service providers and customers in a way that enables goal and resource alignment. This, in turn, is a key prerequisite for value co-creation. In other words, ITSM capability enhances IS effectiveness because it fosters goal and resource alignment between IS and business functions. The inclusion of provider-customer alignment in the internal IT value-creation process and the evidence for its mediating effect are novel contributions to service research in IS. Although prior IS service literature has drawn on the concept of goal and resource alignment in value co-creation $[48,61,65]$, these works did not measure provider-customer alignment. In its nature as a general theory, the service-dominant logic still lacks constructs that can help link its key concepts (e.g., co-creation) to empirical findings in concrete context domains (here, IS services), as authors in related disciplines have argued [10].

While the consideration of provider-customer alignment is new to the service literature in IS, it is consonant with the broader IS literature that has considered the cross-domain alignment between IS functions and business units as an important mediator between various capabilities and organizational performance outcomes (see Online Supplement B). For example, Wu et al. [72] positioned intellectual IS-business alignment as a mediating linkage between IT governance capabilities and firm performance. Bradley et al. [9] demonstrated that intellectual alignment mediates the positive effect of enterprise architecture capabilities on IT agility. Introducing the IS-business alignment construct from the broader IS literature in a service-dominant logic is an important conceptual advancement because it empirically furthers our knowledge on the mechanisms of value co-creation. The notion of provider-customer alignment goes beyond the notion of interaction since interaction itself is not a quality criterion of the provider-customer relationship. There can also be a damaging interaction between providers and customers that destroys value [21]. For this reason, we argue that interaction alone, as embedded in ITSM capability, is a necessary but not sufficient criterion to explain value co-creation. Value cocreation requires purposeful interaction directed at aligning mutual goals and recourses between service providers and customers. The IS-business alignment construct, therefore, fills an important conceptual 
void in the service-dominant logic for IT services by empirically describing the value co-creation mechanism as a mediated effect.

Furthermore, beyond the mediated effect (which accounts for $64 \%$ of the total effect), there is also a direct effect of ITSM capability on IS effectiveness, which leaves reason to assume there is also an alternative mechanism regarding how value is created in internal IT service relationships. Critical views on the service-dominant logic emphasize that value is not necessarily always co-created. In addition to the role of a value co-creator, the service provider can also have a role as a value facilitator $[29,31,32]$. Value facilitation and value co-creation differ by the level of interaction through which the service provider aligns with the service customer [32]. In the understanding of the service provider as a value facilitator, a provider only uses its operant resources to offer access to operand resources that carry potential value in use for the customer [29]. In the value facilitation mechanism, there is no interaction between the service provider and the customer for the creation of value in use. In particular, if no interfaces between a supplier and its customers exist, then the supplier's role is that of a value facilitator [29]. Hence, in this mechanism a customer's value creation is independent of value-enabling alignment activities between the provider and customer. Good examples for value facilitation are cloudbased services that are provisioned and released with minimal service provider interaction [6]. In cloudbased services, the user can decide autonomously via web-based interfaces regarding which services to use and to what extent $[45,71]$. In contrast, in the role as a value co-creator, the service provider engages with the customer's value creation in a joint sphere of direct interactions through co-creational activities and thereby directly influences the customer's creation of value in use [69]. An example of a value co-creator is an IT service provider that provides specialized IT services (e.g., custom software services) to a customer and therefore must cater the design, development, transition, and operation of this service specifically to this customer's needs in multiple loops of close interaction. In the value cocreation mechanism, the service provider and customer relationship is characterized by a high level of interaction in which the provider aligns with the specific goals and resources of the customer [31, 69]. 
Based on the crucial distinction of value facilitation and value co-creation, we contend that it is the value facilitation mechanism that explains the direct effects of ITSM capability on IS effectiveness that remain (with $36 \%$ of the total effect) regardless of the mediated effect through IS-business alignment. The two mechanisms through which value is created — value facilitation and value co-creation — are not mutually exclusive but are complementary, as they occur simultaneously and determine the value generated from specialized resources [29]. Grönroos noted "fundamentally, the firm is a facilitator of value for the customer; [however] provided that the firm can engage with its customers'value-creating processes during direct interactions, it also has opportunities to co-create value jointly with them" [31, p. 294]. For example, a customer may obtain some value from using standard services facilitated by an IT provider, such as standard desktop and printer operations, but then derive additional value from determining how these services can be best aligned with their needs. The result could be more powerful desktop hardware or improved service levels for printer maintenance.

Our partial mediation results therefore underline that co-creation and value facilitation co-occur in internal IS-business service relationships, albeit with varying shares, and thus jointly determine the value in use. Some IT services may require intensive interaction and alignment with goals and resources, while other services may be provided independently from specific goals and business resources. Our finding of a co-occurrence of co-creation and facilitation introduces this important distinction to service research in IS, which has predominantly emphasized the value co-creation mechanism $[34,48,61]$ and thus largely disregarded value facilitation. The relative importance of value facilitation reminds us of the specific nature of IT services as an intangible and electronically mediated resource. Unlike other services (e.g., services in experiential marketing or retail [51]), IT services facilitate the de-coupling of the service provider and the service customers' individual spheres. Our results therefore justify greater attention to the value facilitation mechanism for service research in IS.

Our results also provide support for the hypothesis that the ITSM capability-effectiveness relationship is strengthened by IS strategic conservativeness (H2). This finding emphasizes the important but 
undertheorized role of strategic context in internal IT service relationships. Our results support the theoretical argument that context affects the value in use of operant resources [14]. It is worth noting that our results indicate that IS strategic conservativeness strengthens the direct effect of ITSM capability on IS effectiveness but not the indirect effect through IS-business alignment (Table 5). This suggests that value facilitation is stronger when the IS strategic context of the organization is more conservative, while value co-creation is not.

On one hand, the two-fold finding regarding $\mathrm{H} 2$ provides support for the theoretical argument that ITSM capability carries greater potential value in contexts where organizations take a more exploitative approach in organizational learning and a more stable approach to IT-based innovation. In the presence of such a conservative IS strategy, the routines institutionalized with increasing ITSM capability are well suited to provide value in use to customers that wish to exploit their operand IT resources (i.e., assets such as infrastructure, applications, and skills) through the routinized types of behavior that ITSM capability establishes. Greater ITSM capability likely increases the quality of the existing set of IT services that business customers choose to use and thus enhances IS effectiveness. Organizations with an innovative IS strategy, in contrast, benefit less from the repeatable practices built into ITSM. For the IS innovators, ITSM capability carries relatively lower value in use. Innovative IS functions aim to design new IT services through deploying new IT resources rather than exploiting existing ones. Consequently, the degree of routinization in providing existing services is relatively less important for IS innovators than the development of new services through fundamentally changing the existing ITSM routines.

On the other hand, the findings on $\mathrm{H} 2$ do not support the proposition that ITSM value $c o$-creation is affected by the strategic context since the indirect effect through IS-business alignment is not affected by IS strategic conservativeness (Table 5). A possible explanation for this is that value generation via cocreation is equally important for conservative and innovative organizations. This argument appears plausible given that ITSM capability comprises routines that primarily structure and orchestrate the interactions of IS functions at the interface with business units (as opposed to describing internal 
routines of the IS function). Thus, from a service-dominant perspective, it is the very purpose of specialized ITSM capability to establish a joint sphere between the provider (IS function) and the customer (business) in which alignment of goals and resources can take place. This view is in accordance with the IS alignment literature, which provides ample support for strategic alignment being equally important in both the conservative strategic context of a defender and the innovative strategic context of a prospector company $[12,13,25]$. That is, while the nature of strategic goals is fundamentally different between conservative and innovative organizations, the need for the horizontal alignment across provider-customer boundaries remains undiminished. Conservative organizations may, for example, primarily align on goals for increased IS efficiency, while innovative organizations may primarily align on the design and implementation of new or changed IT services.

Altogether, our two-part findings regarding H2 provide novel evidence that ITSM is subject to a strategy fit rationale. Although some authors have begun to include competitive strategy as a service design dimension in other service domains (e.g., retail services [51]), service researchers in general as well as those in IS have paid scant attention to the role of the strategic context. Integrating our findings on H1 and $\mathrm{H} 2$, our results suggest that value is generated via facilitation vis-à-vis co-creation contingent upon IS strategic conservativeness. Although there is no crisp boundary between value facilitation and value co-creation (i.e., as we argued, both mechanisms co-occur), the balance between the two mechanisms (represented by the extent of the relative mediated effect) varies between IS conservatives and IS innovators. As can be seen from Table 5, for a company with an IS strategic conservativeness that is one standard deviation higher than the average, the indirect effect via IS-business alignment is $56 \%$ of the total effect. For a company that is one standard deviation lower than the average conservativeness (i.e., an innovative company), the mediation via IS-business alignment is $71 \%$ of the total effect.

Although our evidence for the contingency of strategy in internal IT service relationships is a novel contribution to service research in IS, it addresses prior arguments in related strands of work. Benner and Tushman [7] spoke of an inconsistency between exploratory innovation and process management and 
argued that process management activities must be shielded from exploratory activities. Building on this notion of strategy fit (or consistency) in the IS domain, Chen et al. [16] argumentatively derived the proposition that formalization of planning processes is associated with greater planning success for the conservative IS organizations but is associated with lower planning success for IS innovators [p. 248]. Our results provide a more fine-grained picture in which it is neither the conservative nor innovator as Chen et al. [16] implied, but both types of organizations that can derive value from the process management and formalization inherent to building ITSM capability. Nonetheless, not only is the extent of value creation different between both strategy types (conservative organizations derive greater effectiveness benefits), but they also differ in the balance between the value-creation mechanisms. The conservative organizations benefit through value facilitation and co-creation, while IS innovators primarily benefit through value co-creation. Therefore, our distinct and unique contribution is not only to validate and revise the strategy fit proposition of Chen et al. for the domain of IT services but also to advance prior strategy contingency arguments by distinguishing different paths of value creation, leading to a more nuanced understanding of the role of strategic context in IT service relationships.

\section{Theoretical Contributions}

Building on our empirical results, this study offers two key theoretical contributions for the emerging strand of service research in IS. First, by embedding the notion of provider-customer alignment in a service-dominant logic, our results build a bridge from service-dominant logic to the alignment strand of work that has provided robust conceptualizations of the goal alignment between service providers (IS functions) and customers (business units). Although other service researchers have repeatedly demanded the distinction between different value-creation mechanisms [29-32] in response to the emerging service-dominant logic $[68,69]$, prior literature has lacked adequate means to enable researchers to empirically distinguish value co-creation from value facilitation. In particular, the mere level of interaction has been deemed an insufficient criterion to determine the level of co-creation since interaction may also lead to adverse outcomes [21]. Our work employs the notion of goal and resource 
alignment in a service-dominant perspective and provides empirical arguments regarding why this construct can help distinguish the effects of different value-creation mechanisms. We hereby contribute to a more nuanced understanding of the different mechanisms of value creation in IT services.

Second, by providing initial evidence for the contingency of strategic orientation for the effectiveness of a specialized capability, our work advances the proposition that the mechanisms of value creation in service relationships are inherently context specific [14]. While specialized capabilities carry greater potential value in some contexts, they may be devaluated in certain other contexts. Specifically, routinized types of behavior of an organizational capability, such as ITSM capability, generate greater value in proportion to which these patterns are consistent with the desire of the organization to learn based on past experiences with existing routines (i.e., exploitative organizational learning [7, 49]). Such a contingency understanding is particularly useful to recognize the limits of routinization and capability building. Overall, our second key theoretical implication is that service research in IS may not remain context agnostic. Instead, this emerging literature needs to leverage insight from established strands of strategy and organizational learning to explore the context-specific value of resources and capabilities.

\section{Implications for Practice}

The results of this study hold two important implications for companies that scrutinize ITSM with the desire to increase the effectiveness of their IS function. First, organizations are advised to pay special attention to their specific IS strategic orientation when implementing ITSM. Companies with conservative IS strategies will benefit most from implementing ITSM practices since these practices help their IS functions provide access to stable and reliable IT services that facilitate the value creation of business customers. Companies with innovative IS strategies and high agility requirements, in contrast, must ensure that their ITSM implementation efforts do not conflict with their needs for flexibility and innovation.

Second, companies with conservative and innovative IS strategic orientations are advised to put special emphasis on those ITSM practices that orchestrate and improve provider-customer interaction and 
alignment. Focusing on those ITSM routines that involve business stakeholder roles (e.g., service level management, change request management, and incident management) is likely to pay off in improved collaborative adjustment processes needed for aligning goals and resources between business and IS stakeholders, and thus in improved IS effectiveness.

\section{Limitations}

The following limitations merit consideration. First, this self-report study may be subject to deviations from the organizations' real situations that are practically impossible to observe [46]. We took multiple measures to prevent bias in our survey design and controlled for these post-hoc. We are confident in our moderation results since interaction effects are less likely to be artifacts of method bias and they cannot be detected in the presence of substantial method variance [62]. Second, bias may also stem from our data acquisition strategy in which ITSM professionals selected themselves voluntarily into the sample. We controlled for potential bias from multiple industry-, company-, and respondent-level characteristics. Third, our operationalization of IS-business alignment was confined to intellectual and operational cross-domain alignment and did not consider other aspects of cross-domain alignment [26]. Fourth, our cross-sectional data analysis only ascertains association, not the causal effects inherent in our theoretical arguments. Lastly, generalizability may be limited owing to cultural differences since our data acquisition approach focused on members of a professional association in three European countries. In contrast to organizations in other countries such as the US, European companies may rely more heavily on their internal ITSM capability irrespective of targeted IS effectiveness outcomes due to a greater cultural tendency toward uncertainty avoidance [50].

\section{Future Research}

Future research can advance our understanding of value creation in IT services along three particular questions. First, if value co-creation and value facilitation mechanisms co-occur in a portfolio of IT services, what are the characteristic criteria of specific IT services that delineate the enactment of these two distinct value-creation mechanisms? While our study took an organization-level perspective, further 
micro-level empirical studies of sets of IT services are required to identify potential characteristics of services that primarily facilitate value vis-à-vis characteristics of those whose value is primarily cocreated. Second, the question arises: What are further contextual factors that affect the value-creation potential? While we argued for the central role of the IS strategic context, future research may unveil additional firm-level context factors related to a firm's strategy, environment, and culture. Lastly, our study focused on the domain of internal IT services and the IS-business relationship. Future research may explore whether value co-creation and facilitation equally co-occur in external domains of ITenabled services, such as outsourced IT services and cloud-based services, or in service ecosystems. Our study invites future research to enhance our knowledge on the co-occurrence of value co-creation and value facilitation by building on the theoretical contributions emerging from this research.

\section{CONCLUSIONS}

In conclusion, despite the prevalence of a service-dominant approach to the management of IT services, ITSM research to date has largely black-boxed how and when ITSM capability enhances the effectiveness of an IS function and creates value for the business. In one of the first ITSM studies to theorize this problem through the lens of the service-dominant logic, we show that ITSM capability enhances IS effectiveness both directly and indirectly through sustaining the alignment of the IS function with the business. The direct effect (value facilitation) is stronger when the company IS strategy is more conservative. These results provide evidence for a co-occurrence of value co-creation and value facilitation mechanisms in service relationships, whose balance is contingent upon the IS strategic context. More broadly, our results are an initial step to enrich emerging service research in IS with constructs from established strands of alignment and strategy research, in an effort toward a more nuanced understanding of different value-creation mechanisms in service relationships and their contextual contingencies. 


\section{ENDNOTES}

\footnotetext{
${ }^{1}$ Marrone et al. [50] listed various indicators of a growing ITIL adoption, particularly the size of the professional association IT Service Management Forum (itSMF), the robust attendance of itSMF conferences, and the number of ITIL Foundation certificates granted to individuals.

${ }^{2}$ In a meta-analysis, Gerow et al. [25] coded the IS-business alignment construct by Tiwana and Konsynski [67] as covering intellectual alignment and operational alignment types. They also showed that both types of alignment are closely related and hence can be conceptualized as a single construct.

${ }^{3}$ Our labelling of service planning, service transition, and service operation phases was inspired by the phases/domains of the Microsoft Operations Framework (plan) and ITIL (service transition and service operation), respectively.

${ }^{4}$ The scope of IT service management (ITSM) is not restricted to the IS function. Often, ITSM practices are shared with ITSM professionals on the business side. The organizations to which the respondents in our sample reported pertain to the business side and were substantially smaller, which indicates that these respondents may occupy roles that involve both business responsibilities and ITSM responsibilities.
}

${ }^{5}$ The organization owning the ITIL framework accredits licensed examination institutes to examine individuals and to reward credits and titles according to a qualification scheme with five levels: foundation, practitioner, intermediate, expert, and master.

${ }^{6}$ The 22 matched-pair respondents represent $30 \%$ of the 73 respondents who had voluntarily provided names and emails. Our follow-up inquiry included the use of email and phone.

${ }^{7}$ We further calculated a total effect moderation model (reported in Online Supplement E) and ruled out that the moderating effect of conservativeness on the capability-effectiveness relationship results from moderation of the alignment effectiveness link. 


\section{APPENDIX A: MEASURES AND SCALES}

ITSM capability: Respondents were asked to assess the maturity level of ITSM practices on a six-point scale with the anchors defined as follows. 0. None: No recognizable process or not implemented;

1. Initial: Process is ad hoc, or only partially defined; 2 . Repeatable: Process has developed to the stage where similar procedures are followed by different people. There is no formal training or communication of standard procedures, and responsibility is left to the individual. There is a high degree of reliance on the knowledge of individuals; therefore, deviations are likely; 3. Defined: Procedures forming the process have been standardized and documented and have been communicated through training. It is mandated that a process should be followed; however, it is unlikely that deviations will be detected. The procedures themselves are not sophisticated but are rather the formalization of existing practices; 4. Managed: Management monitors and measures compliance with the standardized process and takes action where it appears not to be working effectively. A process is under constant improvement and provides good practice. Automation and tools are used; 5. Optimized: The process has been refined to a level of good practice based on the results of continuous improvement. The IT tools are used in an integrated way to automate the workflow and to improve quality and effectiveness.

The following items were included in the analysis (brief descriptions in parentheses). Service planning capability: SP1. Financial management for IT services (managing an IT service provider's budgeting, accounting, and charging requirements); SP2. Demand management (understanding, anticipating, and influencing customer demand for IT services); SP3. Business relationship management (maintaining a positive relationship with customers); SP4 Availability management (ensuring that IT services meet the current and future availability needs of the business in a cost-effective and timely manner); SP5.

Capacity management (ensuring that the capacity of IT services and the IT infrastructure are able to meet agreed capacity and performance related requirements in a cost-effective and timely manner); SP6. IT service continuity management (managing risks that could seriously affect IT services). 
Service transition capability: ST1. Release and deployment management (planning, scheduling, and controlling the build, test, and deployment of releases); ST2. Service validation and testing (validation and testing of a new or changed IT service); ST3. Evaluation management (formal assessment of a new or changed IT service to ensure that risks have been managed).

Service operation capability: SO1. Change management (controlling the lifecycle of all changes, which enables beneficial changes to be made with minimum disruption to IT services.); SO2. Service asset and configuration management (ensuring that accurate and reliable information about those assets is available when and where it is needed); SO3. Incident management (ensuring that normal service operation is restored as quickly as possible); SO4. Request fulfillment (managing the lifecycle of all service requests); SO5. Problem management (proactively preventing incidents from happening) IS effectiveness: Respondents were asked to estimate the overall performance of the service provider compared to others on a seven-point scale ranging from "far below average" to "far above average" in terms of the following: E1. Efficiency of the service provider in performing the work; E2. Quality of the services provided by the service provider; E3. Support of business/client processes; E4. Satisfaction of the business/client users; E5. Effectiveness of the service provider in supporting the business.

IS-business alignment: Respondents rated the extent to which the service provider is aligned with the following items using a seven-point scale with the endpoints "not at all" and "to a great extent": A1. Business activities; A2. Expectations of business IT users; A3. Needs of business IT users; A4. Demands of business IT users; A5. Business priorities; A6. Business objectives.

For IS strategic conservativeness, respondents were asked to indicate the importance of the following IT goals for their organization (C: conservative; I: innovative) on a seven-point scale from "very low" to "very high": C1. Adopt IT innovations only when they have been proven in the industry; C2. Carefully make decisions concerning IT innovations before implementation; I1. Become a leading IT innovator in the industry; I2. Be the first in the industry to develop new IT initiatives; I3. Respond rapidly to early signals concerning areas of opportunity for IT. 
Regarding control variables, respondents selected their company's main industry segment from one of the following options: Finance and insurance; Information and communication; Manufacturing; Professional, administrative, and public services; Transportation, accommodations, and food services; Utilities, construction, and trade; and Others. The headquarters location was derived from a text field asking for the organization's country of origin. For client size, respondents estimated the number of employees at the IT service provider's client organization as numeric input.

Service orientation was assessed by classifying the core activities of the business on two seven-point dichotomies: Sv1: Manufacturing sector vis-à-vis service sector; Sv2: Physical products vis-à-vis informational products. For regulatory exposure, respondents compared their company's industry with others regarding the following: Reg1. Statutory requirements and laws; Reg2. Other requirements, such as industry standards. The seven-point scale used "much less" and "much more" as end points. The vertical position was captured by asking the respondents for their level (executive management, senior management, management, staff, or other). The horizontal position binary control was captured by asking for affiliation with the IT function vis-à-vis with a business unit. Job tenure was assessed in years in the following intervals: $\langle 1 ; 1-2 ; 2-5 ; 5-10,10-20$, and $>20$. The instrument variable types of IT services (used in Appendix C) was captured as a multiple choice selection from the nine categories reported in Appendix B, Table B1. 


\section{APPENDIX B: SAMPLE CHARACTERISTICS}

Table B1. Sample Characteristics.

\begin{tabular}{|c|c|c|c|c|c|c|c|c|}
\hline Variable & \multicolumn{8}{|c|}{ Distribution (percent), $n=256$} \\
\hline \multirow[t]{2}{*}{ Industry } & $\begin{array}{l}\text { Finance and } \\
\text { insurance } \\
50(19.5 \%)\end{array}$ & \multicolumn{3}{|c|}{$\begin{array}{l}\text { Information and } \\
\text { communication } \\
17(6.6 \%)\end{array}$} & \multicolumn{3}{|c|}{$\begin{array}{l}\text { Manufacturing } \\
54(21.1 \%)\end{array}$} & $\begin{array}{l}\text { Professional, } \\
\text { administrative, and } \\
\text { public services } \\
34(13.2 \%)\end{array}$ \\
\hline & $\begin{array}{l}\text { Transportation, } \\
\text { accommodations } \\
\text { and food services } \\
16(6.3 \%)\end{array}$ & \multicolumn{3}{|c|}{$\begin{array}{l}\text { Utilities, construction, and } \\
\text { trade } \\
26(10.2 \%)\end{array}$} & \multicolumn{3}{|c|}{$\begin{array}{l}\text { Other } \\
59(23.0 \%)\end{array}$} & \\
\hline Employees & \multicolumn{2}{|l|}{$\begin{array}{l}\text { Median } \\
3,000\end{array}$} & \multicolumn{4}{|c|}{$\begin{array}{l}\text { Mean } \\
21,568\end{array}$} & \multicolumn{2}{|c|}{$\begin{array}{l}\text { Standard deviation } \\
56,286\end{array}$} \\
\hline IT employees & \multicolumn{2}{|l|}{$\begin{array}{l}\text { Median } \\
100 \\
\end{array}$} & \multicolumn{4}{|c|}{$\begin{array}{l}\text { Mean } \\
810\end{array}$} & \multicolumn{2}{|c|}{$\begin{array}{l}\text { Standard deviation } \\
3,574\end{array}$} \\
\hline \multirow[t]{3}{*}{$\begin{array}{l}\text { Types of IT } \\
\text { services }\end{array}$} & \multicolumn{2}{|c|}{$\begin{array}{l}\text { Project management } \\
57(22.3 \%)\end{array}$} & \multicolumn{4}{|c|}{$\begin{array}{l}\text { Software development } \\
46(18.0 \%)\end{array}$} & \multicolumn{2}{|c|}{$\begin{array}{l}\text { Application customization } \\
71(27.7 \%)\end{array}$} \\
\hline & \multicolumn{2}{|c|}{$\begin{array}{l}\text { Application management } \\
96(37.5 \%)\end{array}$} & \multicolumn{4}{|c|}{$\begin{array}{l}\text { Datacenter operations } \\
153(59.8 \%)\end{array}$} & \multicolumn{2}{|c|}{$\begin{array}{l}\text { Communication infrastructure } \\
\text { management } 154(60.2 \%)\end{array}$} \\
\hline & \multicolumn{2}{|c|}{$\begin{array}{l}\text { Desktop and printers } \\
\text { management } 153(59.8 \%)\end{array}$} & \multicolumn{4}{|c|}{$\begin{array}{l}\text { Support and help desk } \\
189(73.8 \%)\end{array}$} & \multicolumn{2}{|c|}{$\begin{array}{l}\text { IT training and communication } \\
65(25.4 \%)\end{array}$} \\
\hline $\begin{array}{l}\text { Location of } \\
\text { headquarters }\end{array}$ & \multicolumn{2}{|c|}{$\begin{array}{l}\text { Europe, the Middle East, } \\
\text { and Africa } \\
193(75.4 \%)\end{array}$} & \multicolumn{4}{|c|}{$\begin{array}{l}\text { Americas } \\
36(14.1 \%)\end{array}$} & \multicolumn{2}{|l|}{$\begin{array}{l}\text { Asia Pacific } \\
27(10.5 \%)\end{array}$} \\
\hline $\begin{array}{l}\text { Respondent } \\
\text { position } \\
\text { (horizontally) }\end{array}$ & \multicolumn{4}{|l|}{$\begin{array}{l}\text { Business side } \\
38(14.8 \%)\end{array}$} & \multicolumn{4}{|c|}{$\begin{array}{l}\text { IT function side } \\
218(85.2 \%)\end{array}$} \\
\hline $\begin{array}{l}\text { Position in } \\
\text { organization } \\
\text { (vertically) }\end{array}$ & $\begin{array}{l}\text { Executive } \\
\text { management } \\
16(6.3 \%) \\
\end{array}$ & \multicolumn{2}{|c|}{\begin{tabular}{|l|} 
Senior \\
management \\
$80(31.3 \%)$ \\
\end{tabular}} & \multicolumn{2}{|c|}{$\begin{array}{l}\text { Management } \\
94(36.7 \%) \\
\end{array}$} & \multicolumn{2}{|c|}{ Staff } & Other \\
\hline $\begin{array}{l}\text { Position } \\
\text { tenure }\end{array}$ & $\begin{array}{l}<1 \text { year: } \\
43(16.8 \%)\end{array}$ & \multicolumn{2}{|c|}{$\begin{array}{l}1-2 \text { years: } \\
40(15.6 \%)\end{array}$} & $\begin{array}{l}\text { 2-5 years: } \\
61(23.8 \%)\end{array}$ & \multicolumn{2}{|c|}{$\begin{array}{l}5-10 \text { years: } \\
65(25.4 \%)\end{array}$} & $\begin{array}{l}\text { 10-20 years: } \\
36(14.1 \%)\end{array}$ & \begin{tabular}{|l|}
$>20$ years: \\
$11(4.3 \%)$
\end{tabular} \\
\hline $\begin{array}{l}\text { ITSM } \\
\text { qualification }\end{array}$ & $\begin{array}{l}\text { None } \\
68(26.6 \%)\end{array}$ & $\begin{array}{l}\text { Foundat } \\
92(35.9\end{array}$ & & $\begin{array}{l}\text { Interme } \\
33(12.9\end{array}$ & $\begin{array}{l}\text { iate }^{\mathrm{a}} \\
\%)\end{array}$ & & $8 \%)$ & $\begin{array}{l}\text { Master } \\
2(0.8 \%)\end{array}$ \\
\hline
\end{tabular}

a including practitioner level. 


\section{APPENDIX C: ENDOGENEITY BIAS ASSESSMENT}

In our model, ITSM capability might be endogenous because the level of ITSM capability could be deliberately chosen based on the IT service provider's expectation of which level will produce the most desirable outcome. In this case, a model that does not account for endogeneity would generate biased results since the assumption that the error term in the OLS regression is uncorrelated with the predictor would be violated.

For this reason, we tested for endogeneity in our model using Garen's [24] two-step econometric procedure. Following Tiwana and Kim [66], we estimated a reduced form model by first computing an endogeneity correcting $\eta$ for ITSM capability and, second, including $\eta$ in the model that contains the potentially endogenous predictor. The choice of instruments chosen in the first step should optimally be guided by theory. An important aspect in the design of ITSM capability is the types of IT services included in the service portfolio [42]. While some services that address the development and operation of applications require a broad set of capabilities related to service design, transition, and operation, others focus on infrastructure capabilities (e.g., network management) or on service design capabilities (e.g., IT project management) [35]. Hence, we contend that a service provider's level of ITSM capability is influenced by the types of services offered. As a second instrument, IT service provider size might influence ITSM capability. Prior ITSM studies indicate that smaller organizations tend to rely on less formal working relationships, while larger organizations often accomplish coordination through highly formalized service management routines [50].

The results of the first step are depicted in Table C1. Regarding service types, the results show that the provision of IT services that belong to the project management and application customization types positively influences the level of ITSM capability, while service provider size has no influence. The first stage model's relatively low $\mathrm{F}$ value of 4.625 is acceptable given the scarce empirical research on antecedents of ITSM capability. 
Table C1. Step 1 of the Garen Procedure to Evaluate Endogeneity in ITSM capability.

\begin{tabular}{|l|r|}
\hline Instrument variables & ITSM capability \\
\hline Intercept & $-.540^{* * *}(-3.586)$ \\
\hline Project management (dummy) & $.370^{*}(2.361)$ \\
\hline Software development (dummy) & $-.114(-.619)$ \\
\hline Application customization (dummy) & $.389^{*}(2.357)$ \\
\hline Application management (dummy) & $-.060(-.440)$ \\
\hline Datacenter operations (dummy) & $.288(1.595)$ \\
\hline Communication infrastructure management (dummy) & $.073(.387)$ \\
\hline Desktop and printers management $($ dummy) & $-.077(-.465)$ \\
\hline Support and help desk (dummy) & $-.091(-.535)$ \\
\hline IT training and communication (dummy) & $.145(.999)$ \\
\hline IT service provider size \# of employees log transformed) & $.125(1.803)$ \\
\hline \hline$R^{2}(F)$ & $.159^{* * *}(4.625)$ \\
\hline${ }^{*} p<.05 ;{ }^{* *} p<.01 ;{ }^{* * *} p<.001$ & \\
\hline
\end{tabular}

In the second step, we included the error term $\eta$ of the first step as a predictor in the prediction model for IS effectiveness (Table C2). The Breusch-Pagan test for non-constant error variance [19] asserts the absence of heteroscedasticity $\left(\chi^{2}=0.256, p=.613\right)$ and thus the validity of our second-step regression result. The nonsignificant value of $\eta$ in the second-step regression and the nonsignificant $\chi^{2}$ statistic of the Wu-Hausman test for endogeneity $(0.499, p=.684)$ assert that OLS regression is as consistent as instrument variable regression.

We used the Anderson and Rubin test for instrument sufficiency [2]. The null hypothesis is that the excluded instruments are uncorrelated with the error term, and the significance indicates the insufficiency of the instruments. The Anderson and Rubin test statistic was nonsignificant (1.414; $p=.174)$. This suggests that the set of instruments used is sufficient and valid.

To test over-identifying restrictions, we used the Sargan test [60]. The null hypothesis is that the overidentifying restrictions in the model are valid. The nonsignificant test statistic $(\chi 2=5.646, p=.582)$ does not reject the null hypothesis and suggests that the model was appropriately overidentified. 
Table C2. Step 2 of the Garen Procedure to Check Endogeneity in the Prediction of IS Effectiveness.

\begin{tabular}{|l|r|}
\hline Variable & IS effectiveness \\
\hline Intercept & $.016(0.302)$ \\
\hline ITSM capability & $.503^{* * *}(3.368)$ \\
\hline Conservativeness & $-.078(-1.898)$ \\
\hline Conservativeness ${ }^{*}$ ITSM capability & $.117^{* *}(2.798)$ \\
\hline$\eta_{\text {ITSM capability }}$ & $-.032(-0.203)$ \\
\hline \hline$R^{2}(F)$ & $0.238^{* * *}(19.59)$ \\
\hline${ }^{*} p<.05 ;{ }^{* *} p<.01,{ }^{* * *} p<.001$ & \\
\hline
\end{tabular}

\section{REFERENCES}

1. Abdullah, N.S.; Sadiq, S.; and Indulska, M. Emerging challenges in information systems research for regulatory compliance management. International Conference on Advanced Information Systems Engineering: Springer, 2010, pp. 251-265.

2. Anderson, T.; and Rubin, H. Estimators of the parameters of a single equation in a complete set of stochastic equations. The Annals of Mathematical Statistics, 20, 1 (1949), 46-63.

3. Bardhan, I.R.; Demirkan, H.; Kannan, P.; Kauffman, R.J.; and Sougstad, R. An interdisciplinary perspective on IT services management and service science. Journal of Management Information Systems, 26, 4 (2010), 13-64.

4. Baron, R.M.; and Kenny, D.A. The moderator-mediator variable distinction in social psychological research: Conceptual, strategic, and statistical considerations. Journal of Personality and Social Psychology, 51, 6 (1986), 1173-1182.

5. Barrett, M.; Davidson, E.; Prabhu, J.; and Vargo, S.L. Service innovation in the digital age: key contributions and future directions. MIS Quarterly, 39, 1 (2015), 135-154.

6. Benlian, A.; Kettinger, W.J.; Sunyaev, A.; and Winkler, T.J. The transformative value of cloud computing: A decoupling, platformization, and recombination theoretical framework. Journal of Management Information Systems, 35, 3 (2018), 719-739.

7. Benner, M.J.; and Tushman, M.L. Exploitation, exploration, and process management: The productivity dilemma revisited. Academy of Management Review, 28, 2 (2003), 238-256.

8. Bloomberg, J. DevOps and ITIL: Friends or enemies? Forbes.com (2015), (accessed 2018/11/20 at https://www.forbes.com/sites/jasonbloomberg/2015/11/13/devops-and-itil-friends-or-enemies/)

9. Bradley, R.V.; Pratt, R.M.; Byrd, T.A.; Outlay, C.N.; and Wynn Jr, D.E. Enterprise architecture, IT effectiveness and the mediating role of IT alignment in US hospitals. Information Systems Journal, 22, 2 (2012), 97-127.

10. Brodie, R.J.; Saren, M.; and Pels, J. Theorizing about the service dominant logic: The bridging role of middle range theory. Marketing Theory, 11, 1 (2011), 75-91.

11. Cannon, D.; Hanna, A.; Hunnebeck, L.; Lacy, S.; Lloyd, V.; Macfarlane, I.; Rudd, C.; Steinberg, R.A.; Taylor, S.; and Wheeldon, D. ITIL version 3 book series (service strategy, service design, service transition, service operation) Norwith, UK: TSO (The Stationery Office), 2011.

12. Chan, Y.E.; Huff, S.L.; and Copeland, D.G. Assessing realized information systems strategy. The Journal of Strategic Information Systems, 6, 4 (1997), 273-298.

13. Chan, Y.E.; and Reich, B.H. IT alignment: What have we learned? Journal of Information Technology, 22, 4 (2007), 297-315.

14. Chandler, J.D.; and Vargo, S.L. Contextualization and value-in-context: How context frames exchange. Marketing theory, 11, 1 (2011), 35-49.

15. Chang, J.C.J.; and King, W. Measuring the performance of information systems: A functional scorecard. Journal of Management Information Systems, 22 (2005), 85-115. 
16. Chen, D.Q.; Mocker, M.; Preston, D.S.; and Teubner, A. Information systems strategy: Reconceptualization, measurement, and implications. MIS Quarterly, 34, 2 (2010), 233-259.

17. Chien, S.-H.; and Chen, J.-J. Supplier involvement and customer involvement effect on new product development success in the financial service industry. The Service Industries Journal, 30, 2 (2010), 185-201.

18. Coltman, T.; Tallon, P.; Sharma, R.; and Queiroz, M. Strategic IT alignment: Twenty-five years on. Journal of Information Technology, 30, 2 (2015), 91-100.

19. Cook, R.D.; and Weisberg, S. Diagnostics for heteroscedasticity in regression. Biometrika, 70, 1 (1983), 1-10.

20. Dong, B.; Evans, K.R.; and Zou, S. The effects of customer participation in co-created service recovery. Journal of the Academy of Marketing Science, 36, 1 (2008), 123-137.

21. Echeverri, P.; and Skålén, P. Co-creation and co-destruction: A practice-theory based study of interactive value formation. Marketing Theory, 11, 3 (2011), 351-373.

22. Edwards, J.R.; and Lambert, L.S. Methods for integrating moderation and mediation: A general analytical framework using moderated path analysis. Psychological Methods, 12, 1 (2007), 1-22.

23. Galup, S.D.; Dattero, R.; Quan, J.J.; and Conger, S. An overview of IT service management. Communications of the ACM, 52, 5 (2009), 124-127.

24. Garen, J. The returns to schooling: A selectivity bias approach with a continuous choice variable. Econometrica: Journal of the Econometric Society (1984), 1199-1218.

25. Gerow, J.E.; Grover, V.; Thatcher, J.; and Roth, P.L. Looking toward the future of IT-business strategic alignment through the past: A meta-analysis. MIS Quarterly, 38, 4 (2014), 1059-1085.

26. Gerow, J.E.; Thatcher, J.B.; and Grover, V. Six types of IT-business strategic alignment: An investigation of the constructs and their measurement. European Journal of Information Systems, 24, 5 (2014), 1-27.

27. Goldstein, S.M.; Johnston, R.; Duffy, J.; and Rao, J. The service concept: The missing link in service design research? Journal of Operations Management, 20, 2 (2002), 121-134.

28. Goode, S.; and Gregor, S. Rethinking organisational size in IS research: Meaning, measurement and redevelopment. European Journal of Information Systems, 18, 1 (2009), 4-25.

29. Grönroos, C. Service logic revisited: Who creates value? And who co-creates? European Business Review, 20, 4 (2008), 298-314.

30. Grönroos, C. A service perspective on business relationships: The value creation, interaction and marketing interface. Industrial Marketing Management, 40, 2 (2011), 240-247.

31. Grönroos, C. Value co-creation in service logic: A critical analysis. Marketing Theory, 11, 3 (2011), 279-301.

32. Grönroos, C.; and Voima, P. Critical service logic: Making sense of value creation and co-creation. Journal of the Academy of Marketing Science, 41, 2 (2013), 133-150.

33. Grover, V.; Jeong, S.R.; and Segars, A.H. Information systems effectiveness: The construct space and patters of application. Information \& Management, 31, 4 (1996), 177-191.

34. Grover, V.; and Kohli, R. Cocreating IT value: New capabilities and metrics for multifirm environments. MIS Quarterly, 36, 1 (2012), 225-232.

35. Han, S.; Kuruzovich, J.; and Ravichandran, T. Service expansion of product firms in the information technology industry: An empirical study. Journal of Management Information Systems, 29, 4 (2013), 127-158.

36. Iden, J.; and Eikebrokk, T.R. Implementing IT service management: A systematic literature review. International Journal of Information Management, 33, 3 (2013), 512-523.

37. Iden, J.; and Eikebrokk, T.R. Using the ITIL process reference model for realizing IT governance: An empirical investigation. Information Systems Management, 31, 1 (2014), 37-58.

38. James, L.R.; Demaree, R.G.; and Wolf, G. rwg: An assessment of within-group interrater agreement. Journal of Applied Psychology, 78, 2 (1993), 306. 
39. Jansen, J.J.P.; Van Den Bosch, F.A.J.; and Volberda, H.W. Exploratory innovation, exploitative innovation, and performance: Effects of organizational antecedents and environmental moderators. Management Science, 52, 11 (2006), 1661-1674.

40. Jobe, J.B. Cognitive psychology and self-reports: Models and methods. Quality of Life Research, 12, 3 (2003), 219-227.

41. Johns, G. The essential impact of context on organizational behavior. Academy of Management Review, 31, 2 (2006), 386-408.

42. Kaitovaara, P.; and Nurminen, M.I. IT artefacts in IT services: Toward a taxonomy. Proceedings of the Action in Language, Organisations and Information Systems (2003), 71-84.

43. Kathuria, A.; Mann, A.; Khuntia, J.; Saldanha, T.J.; and Kauffman, R.J. A strategic value appropriation path for cloud computing. Journal of Management Information Systems, 35, 3 (2018), 740-775.

44. Kearns, G.S.; and Lederer, A.L. The impact of industry contextual factors on IT focus and the use of IT for competitive advantage. Information \& Management, 41, 7 (2004), 899-919.

45. Krancher, O.; Luther, P.; and Jost, M. Key Affordances of platform-as-a-service: Self-organization and continuous feedback. Journal of Management Information Systems, 35, 3 (2018), 776-812.

46. Kumar, N.; Stern, L.W.; and Anderson, J.C. Conducting interorganizational research using key informants. Academy of Management Journal, 36, 6 (1993), 1633-1651.

47. Leidner, D.E.; Lo, J.; and Preston, D. An empirical investigation of the relationship of IS strategy with firm performance. The Journal of Strategic Information Systems, 20, 4 (2011), 419-437.

48. Lempinen, H.; and Rajala, R. Exploring multi-actor value creation in IT service processes. Journal of Information Technology, 29, 2 (2014), 170-185.

49. March, J.G. Exploration and exploitation in organizational learning. Organization Science, 2,1 (1991), 71-87.

50. Marrone, M.; Gacenga, F.; Cater-Steel, A.; and Kolbe, L. IT service management: A cross-national study of ITIL adoption. Communications of the Association for Information Systems, 34, 1 (2014), 865-892.

51. Miles, P.; Miles, G.; and Cannon, A. Linking servicescape to customer satisfaction: Exploring the role of competitive strategy. International Journal of Operations \& Production Management, 32, 7 (2012), 772-795.

52. Miles, R.E.; Snow, C.C.; Meyer, A.D.; and Coleman, H.J., Jr. Organizational Strategy, Structure, and Process. The Academy of Management Review, 3, 3 (1978), 546-562.

53. Nadler, D.A.; and Tushman, M.L. A model for diagnosing organizational behavior. Organizational Dynamics, 9, 2 (1980), 35-51.

54. Payne, A.F.; Storbacka, K.; and Frow, P. Managing the co-creation of value. Journal of the Academy of Marketing Science, 36, 1 (2008), 83-96.

55. Podsakoff, P.M.; MacKenzie, S.B.; Lee, J.-Y.; and Podsakoff, N.P. Common method biases in behavioral research: A critical review of the literature and recommended remedies. Journal of Applied Psychology, 88, 5 (2003), 879-903.

56. Podsakoff, P.M.; and Organ, D.W. Self-reports in organizational research: Problems and prospects. Journal of Management, 12, 4 (1986), 531-544.

57. Porter, M.E. Competitive strategy: Techniques for analyzing industries and competition. New York: Simon and Schuster, 1980.

58. Ravichandran, T.; and Rai, A. Total quality management in information systems development: Key constructs and relationships. Journal of Management Information Systems, 16, 3 (1999), 119-155.

59. Retana, G.; Forman, C.; Narasimhan, S.; Niculescu, M.F.; and Wu, D. Technology support and post-adoption IT service use: Evidence from the cloud. MIS Quarterly, 42, 3 (2018), 961-978.

60. Sargan, J.D. The estimation of economic relationships using instrumental variables. Econometrica, 26 3(1958), 393-415. 
61. Sarker, S.; Sarker, S.; Sahaym, A.; and Bjørn-Andersen, N. Exploring value cocreation in relationships between an ERP vendor and its partners: A revelatory case study. MIS Quarterly, 36, 1 (2012), 317-338.

62. Siemsen, E.; Roth, A.; and Oliveira, P. Common method bias in regression models with linear, quadratic, and interaction effects. Organizational Research Methods, 13, 3 (2010), 456-476.

63. Spector, P.E.; and Brannick, M.T. Methodological urban legends: The misuse of statistical control variables. Organizational Research Methods, 14, 2 (2011), 287-305.

64. Tabachnick, B.G.; and Fidell, L.S. Using multivariate statistics. Boston: Pearson Education, 2007.

65. Tallon, P.P. A service science perspective on strategic choice, IT, and performance in US banking. Journal of Management Information Systems, 26, 4 (2010), 219-252.

66. Tiwana, A.; and Kim, S.K. Concurrent IT sourcing: Mechanisms and contingent advantages. Journal of Management Information Systems, 33, 1 (2016), 101-138.

67. Tiwana, A.; and Konsynski, B. Complementarities between organizational IT architecture and governance structure. Information Systems Research, 21, 2 (2010), 288-304.

68. Vargo, S.L.; and Lusch, R.F. Evolving to a new dominant logic for marketing. Journal of Marketing, 68, 1 (2004), 1-17.

69. Vargo, S.L.; and Lusch, R.F. Service-dominant logic: continuing the evolution. Journal of the Academy of Marketing Science, 36, 1 (2008), 1-10.

70. Wagner, H.-T.; Beimborn, D.; and Weitzel, T. How social capital among information technology and business units drives operational alignment and IT business value. Journal of Management Information Systems, 31, 1 (2014), 241-272.

71. Winkler, T.J.; and Brown, C.V. Horizontal allocation of decision rights for on-premise applications and software-as-a-service. Journal of Management Information Systems, 30, 3 (2013), 13-48.

72. Wu, S.P.-J.; Straub, D.W.; and Liang, T.-P. How information technology governance mechanisms and strategic alignment influence organizational performance: Insights from a matched survey of business and IT managers. MIS Quarterly, 39, 2 (2015), 497-A497. 


\section{SUPPLEMENT A: REVIEW OF THE IT SERVICE MANAGEMENT LITERATURE}

In preparation for this study on the effectiveness of IT service management (ITSM) capability, we conducted a systematic review of the prior empirical literature on ITSM. This review focused on prior conceptualizations related to our focal construct (ITSM capability), potential outcome dimensions, the employed theories, and the research methodologies. The search strategy was as follows. We chose the review by Iden and Eikebrokk [18] as a starting point, conducted a forward search from this article, and backward searched all referenced articles. Table A1 provides an overview of the reviewed studies.

Table A1. Prior Empirical Research on Information Technology Service Management (ITSM) Outcomes.

\begin{tabular}{|c|c|c|c|c|c|c|c|c|c|}
\hline Reference & $\begin{array}{c}\text { Research } \\
\text { method }\end{array}$ & $\begin{array}{l}\text { Measurement of } \\
\text { ITSM }\end{array}$ & Theory & $\mathbf{S E}^{*}$ & $\mathbf{S Q}^{*}$ & $\mathrm{CS}^{*}$ & $\mathbf{P E}^{*}$ & $\mathbf{S E}^{*}$ & Other outcomes \\
\hline Cots et al. [6] & Survey & None & None & $\mathrm{X}$ & $\mathrm{X}$ & $\mathrm{X}$ & $\mathrm{X}$ & $\mathrm{X}$ & $\begin{array}{l}\text { - Staff motivation } \\
\text { - Plan and control } \\
\text { - Quality culture }\end{array}$ \\
\hline $\begin{array}{l}\text { Gacenga et al. } \\
{[10]}\end{array}$ & Survey & $\begin{array}{l}\text { Number of ITSM } \\
\text { practices (binary) }\end{array}$ & None & $\mathrm{X}$ & $\mathrm{X}$ & $\mathrm{X}$ & $\mathrm{X}$ & & $\begin{array}{l}\text { - Reduced costs for } \\
\text { implementing change } \\
\text { - Better information } \\
\text { - Working relationships } \\
\text { - Service flexibility and } \\
\text { adaptability }\end{array}$ \\
\hline $\begin{array}{l}\text { Gacenga et al. } \\
\text { [9] }\end{array}$ & $\begin{array}{l}\text { Multiple } \\
\text { case study }\end{array}$ & None & $\begin{array}{l}\text { Contingency } \\
\text { theory }\end{array}$ & $\mathrm{X}$ & $\mathrm{X}$ & $\mathrm{X}$ & & & $\begin{array}{l}\text { - Technology-level } \\
\text { consumption } \\
\text { - Fewer incidents }\end{array}$ \\
\hline $\begin{array}{l}\text { Hochstein et } \\
\text { al. [17] }\end{array}$ & $\begin{array}{l}\text { Multiple } \\
\text { case study }\end{array}$ & None & None & $\mathrm{X}$ & $\mathrm{X}$ & $\mathrm{X}$ & & & None \\
\hline $\begin{array}{l}\text { Iden and } \\
\text { Eikebrokk } \\
{[20]}\end{array}$ & Survey & $\begin{array}{l}25 \text { ITSM practice } \\
\text { items (scaled) }\end{array}$ & $\begin{array}{l}\text { Contingency } \\
\text { theory }\end{array}$ & $\mathrm{X}$ & $\mathrm{X}$ & $\mathrm{X}$ & & & - Focus on IT services \\
\hline $\begin{array}{l}\text { Kashanchi } \\
\text { and Toland } \\
{[21]}\end{array}$ & $\begin{array}{l}\text { Multiple } \\
\text { case study }\end{array}$ & None & $\begin{array}{l}\text { IS-business } \\
\text { alignment }\end{array}$ & $\mathrm{X}$ & $\mathrm{X}$ & & $\mathrm{X}$ & $\mathrm{X}$ & $\begin{array}{l}\text { - Knowledge sharing } \\
\text { - Process consistency }\end{array}$ \\
\hline $\begin{array}{l}\text { Marrone and } \\
\text { Kolbe [23] }\end{array}$ & Survey & $\begin{array}{l}\text { Single ITSM } \\
\text { process maturity } \\
\text { (scaled), Number of } \\
\text { ITSM practices } \\
\text { (binary) }\end{array}$ & None & $\mathrm{X}$ & $\mathrm{X}$ & $\mathrm{X}$ & & $\mathrm{X}$ & $\begin{array}{l}\text { - Standardization } \\
\text { - IS-business alignment } \\
\text { - Downtime reduction } \\
\text { - Call resolution rate } \\
\text { - IT staff morale }\end{array}$ \\
\hline $\begin{array}{l}\text { Marrone and } \\
\text { Kolbe [24] }\end{array}$ & Survey & $\begin{array}{l}\text { Single ITSM } \\
\text { process maturity } \\
\text { factor (scaled) }\end{array}$ & None & $\mathrm{X}$ & $\mathrm{X}$ & $\mathrm{X}$ & & $\mathrm{X}$ & See Marrone and Kolbe [23] \\
\hline $\begin{array}{l}\text { Moura et al. } \\
{[25]}\end{array}$ & Case Study & None & $\begin{array}{l}\text { Balanced } \\
\text { Scorecard }\end{array}$ & & $\mathrm{X}$ & & $\mathrm{X}$ & $\mathrm{X}$ & $\begin{array}{l}\text { - Customer class losses } \\
\text { - Internal operations } \\
\text { - Learning/innovation } \\
\text { - Financial losses }\end{array}$ \\
\hline $\begin{array}{l}\text { Potgieter et } \\
\text { al. [29] }\end{array}$ & Survey & $\begin{array}{l}\text { Number of ITSM } \\
\text { practices (binary) }\end{array}$ & None & $\mathrm{X}$ & $\mathrm{X}$ & $\mathrm{X}$ & & & $\begin{array}{l}\text { - Calls per user } \\
\text { - Resource availability } \\
\end{array}$ \\
\hline Wagner [37] & Case Study & $\begin{array}{l}\text { Assimilation as a } \\
\text { process }\end{array}$ & $\begin{array}{l}\text { Resource- } \\
\text { based view }\end{array}$ & & & $\mathrm{X}$ & & & $\begin{array}{l}\text { - Proactiveness } \\
\text { - Understanding of business } \\
\text { requirements }\end{array}$ \\
\hline $\begin{array}{l}\text { Wan and } \\
\text { Chan [39] }\end{array}$ & Case study & $\begin{array}{l}\text { Assimilation as a } \\
\text { process }\end{array}$ & None & $\mathrm{X}$ & $\mathrm{X}$ & & & & None \\
\hline
\end{tabular}

${ }^{*} \mathrm{SE}=$ IT service efficiency, $\mathrm{SQ}=$ IT service quality, $\mathrm{CS}=$ customer satisfaction, $\mathrm{PE}=$ business process effectiveness, $\mathrm{SE}=$ strategic effectiveness 
The review reveals two major gaps in the empirical ITSM literature. First, prior empirical ITSM literature has been limited in measuring ITSM capability by focusing merely on aspects of adoption and/or not distinguishing the different phases of the IT service lifecycle. Two survey studies used scaled measures to measure degrees of ITSM adoption: Iden and Eikebrokk [20] operationalized the ITSM implementation progress as a formative construct (not started, early, halfway, advanced, and completed) of 25 individual ITSM practices. Marrone and Kolbe $[23,24]$ used a single item to measure overall ITSM maturity (initial, repeatable, defined, managed, and optimized). Three other survey studies used binary measures (i.e., adopted or not adopted) to measure ITSM adoption as a simple aggregate count of the adopted ITSM practices $[10,23,29]$.

An ITSM capability, however, forms during and beyond the mere act of adopting ITSM practices [37], and it covers distinct phases of the IT service lifecycle $[4,7,14,28]$. To address these issues, the ITSM capability construct used in the present study measures the individual stages of practice maturity on a welldescribed maturity scale, which builds on the widely accepted Capability Maturity Model Integration (CMMI) model [27], and it takes into account the three phases of the IT service lifecycle (service planning, service transition, and service operation) as its first-order dimensions.

Second, the empirical ITSM literature lacks a coherent theoretical understanding of how and under which conditions ITSM practices generate the intended effects. Six of the 12 identified articles find empirical evidence for various ITSM outcomes, including IT service efficiency, IT service quality, customer satisfaction, business process effectiveness, and strategic effectiveness (see Table A1). Only five of the 12 studies make use of an underlying reference theory to explain the relation of ITSM with these outcomes, whereas these explanatory lenses vary. Kashanchi and Toland [21] cautiously posed the question of whether ITSM can achieve benefits through contributing to IS-business alignment. Iden and Eikebrokk [19] and Gacenga et al. [9] used contingency theory to identify internal and external factors that may have an influence on ITSM performance. Moura et al. [25] proposed balanced scorecard concepts for developing a quantitative approach to investment allocation for ITIL financial management. The single 
case study by Wagner [37] adopted a resource-based view, arguing that ITSM performance is due to resource-based learning loops and routines. It is worth noting that none of the reviewed studies use theory to conceptualize the role of potentially important contextual factors that may influence the achievement of ITSM outcomes as a contingent factor.

In summary, we know little about the effects of ITSM capability on organizational effectiveness outcomes. The sparse prior empirical ITSM research has remained limited in that is does not measure ITSM capability across different IT service lifecycle phases. Further, it does not theoretically explain how and under which contingencies these effects are achieved. Hence, the effects of ITSM capability have remained theoretically and empirically black boxed. The present study addresses these gaps in our knowledge by drawing on the service dominant logic as a theoretical lens that emphasizes different modes of value creation from ITSM capability. 


\section{SUPPLEMENT B: ALIGNMENT DEFINITIONS}

The Information Systems (IS) field has a long-standing tradition in research on alignment [12]. This rich literature has provided numerous ways of conceptualizing and measuring different types of alignment as research constructs. Since the terminology and definitions of these constructs are not always consistent, in Figure B1, we provide a morphological box that displays the conceptualization of the IS-business alignment construct used in this research vis-à-vis distinct conceptualization choices and construct variants offered by the literature.

First, alignment can be either viewed as a state or a process [3]. Studies that view alignment as a state predominantly take a variance-theoretical stance by measuring a level of alignment at a given point in time [e.g., 13, 30] . In contrast, process-theoretical approaches emphasize how business strategies and associated IT requirements are subject to permanent drifts and are therefore in continuous need of mutual adjustment activities [11,33]. This present study adopts the perspective of alignment as a state by considering the IS-business alignment at a specific organization and a specific point in time as the measurable result of alignment activities. This perspective is adequate to explore the role of IS-business alignment as a mechanism that mediates ITSM effects [5], and it is also compatible with the cross-sectional nature of our data.

Figure B1. Morphological Box of Alignment Conceptualizations (Author Choices Highlighted).

\begin{tabular}{|c|c|c|c|c|c|c|}
\hline \multirow[t]{2}{*}{ Notion } & Dynamism & \multicolumn{2}{|c|}{ State } & \multicolumn{3}{|c|}{ Process } \\
\hline & Directionality & \multicolumn{2}{|c|}{ Unidirectional } & \multicolumn{3}{|c|}{ Bidirectional } \\
\hline \multirow{2}{*}{\multicolumn{2}{|c|}{ Types }} & \multicolumn{2}{|c|}{ Within-domain } & \multicolumn{3}{|c|}{ Cross-domain (business-IS) } \\
\hline & & $\begin{array}{c}\text { Strategic } \\
\text { business alignment }\end{array}$ & $\begin{array}{l}\text { Strategic } \\
\text { IS alignment }\end{array}$ & $\begin{array}{l}\text { Intellectual } \\
\text { alignment }\end{array}$ & $\begin{array}{l}\text { Operational } \\
\text { alignment }\end{array}$ & $\begin{array}{c}\text { Social } \\
\text { alignment }\end{array}$ \\
\hline & & \multicolumn{5}{|c|}{ Y } \\
\hline \multicolumn{2}{|l|}{ Subjects } & $\begin{array}{ll}\text { - } & \text { Strategies } \\
\text { - } & \text { Missions } \\
\text { - } & \text { Objectives } \\
\text { - } & \text { Plans } \\
\text { - } & \ldots\end{array}$ & \multicolumn{2}{|c|}{$\begin{array}{ll}\text { - } & \text { Skills } \\
\text { - } & \text { Procedures } \\
\text { - } & \text { Demands } \\
\text { - } & \text { Activities } \\
\text { - } & \ldots\end{array}$} & \multicolumn{2}{|c|}{$\begin{array}{l}\text { - } \text { - Shared understanding } \\
\text { - Commitment } \\
\text { - Communication } \\
\text { - } \quad \text { Culture } \\
\end{array}$} \\
\hline \multicolumn{2}{|c|}{ Measurement } & \multicolumn{2}{|c|}{ Direct } & \multicolumn{3}{|c|}{ Indirect } \\
\hline \multicolumn{2}{|c|}{ Nomological role } & Antecedent & \multicolumn{2}{|c|}{ Mediator } & \multicolumn{2}{|c|}{ Outcome } \\
\hline
\end{tabular}


Second, prior alignment studies in IS are sometimes vague about whether alignment is understood as being unidirectional or bidirectional. While the alignment literature has traditionally implied that one component (e.g., IS strategy) is subordinate to or lags behind the other component (e.g., the business strategy) and thus needs to be aligned with the other in an unidirectional fashion, the emergence of digital business strategy has given rise to works that explicitly account for the bidirectional linkage between these components, or what prior authors have called two-way strategic IT alignment [16]. In this study of the mediating role of IS-business alignment in IT service relationships, we confine ourselves to a unidirectional conceptualization of IS-business alignment to account for the subordinate role of the IT service provider. The notion of unidirectionality is inherent to the notion of service as an activity of one entity acting for the benefit of another entity [35, p. 2].

Third, depending on the organizational components that are in the focus of alignment, different types of alignment have been discussed, including strategic, intellectual, operational, and social alignment [13]. The strategic alignment model by Henderson and Venkatraman [15] defines four components, two in the business domain (business strategy and organizational infrastructure) and two in the IS domain (IS strategy and IS infrastructure). Of all pairwise linkages between these components, strategic alignment, in its original sense, refers to the vertical linkages within each domain (labelled business strategic alignment and IS strategic alignment in Figure B1). Henderson and Venkatraman [15] also referred to these vertical linkages of organizational infrastructure and processes with its strategy and external environment as strategic integration and strategic fit.

Of major interest for IS research, however, has been those types of alignment that horizontally span the business and IS domains (i.e., different types of cross-domain alignment). Here, the primary attention has been on the "link between business strategy and I/T strategy reflecting the external components" [15, $\mathrm{p}$. 476]. Later, this construct has been termed intellectual alignment and defined as "the state in which a high quality set of inter-related IT and business plans exist" [32, p. 82]. Besides its focus on aligning strategy, 
key aspects of intellectual alignment also include missions and objectives [31, p. 3], plans and planning [22], and orientation [2].

Relatively less attention has been drawn to the "link between organizational infrastructure [...] and I/S infrastructure" [15, p. 476], more commonly to referred to as operational alignment [13]. Operational alignment can be defined as "cross-domain interconnectedness comprising social capital between IT and business departments and their common knowledge base" [38, p. 243], and according to these authors, it is equally as important as intellectual alignment to derive business value from IT. Key aspects of business and IS infrastructure include procedures, skills, resources, and activities [13].

Social alignment has been defined as "the state in which business and IT executives within an organizational unit understand and are committed to the business and IT mission, objectives, and plans" [32, p. 81]. Prior reviews of the alignment literature have considered social alignment to be an influencing context variable for IS-business alignment, rather than a dedicated type of alignment [12]. Lastly, diagonal cross-domain linkages (i.e., linkages between business strategy and IT infrastructure, or IT strategy and business infrastructure) have not specifically been defined and measured by the literature [13, p. 14].

The IS-business alignment construct used in this study was adopted from prior research [34] and defined as the degree to which the IS function supports the needs, demands, and goals of an organization's business functions. This definition is consistent with the notion of congruence in organizations as "the degree to which the needs, demands, goals, and/or structures of one component are consistent with the needs, demands, goals, and/or structures of another component" [26, p. 45]. Given this relatively broad focus, prior meta-reviews assert that this construct covers aspects of both intellectual and operational alignment [12, p. 1185]. We argue that this dual focus on intellectual and operational aspects of alignment, excluding social alignment [12], is adequate for the purpose of this study since the ITSM capabilities covering different phases of the IT service lifecycle (i.e., service planning, transition, and operation) potentially affect multiple aspects of intellectual and operational alignment. 
Fourth, prior alignment research has used both direct and indirect measures of alignment. Traditionally, much attention has been given to indirect measures of alignment that assess different components (e.g., business and IS strategy) separately by drawing on one of the fit perspectives proposed by Venkatraman [36], foremost the matching, moderation, and profile deviation fit perspectives [5]. However, the use of indirect measures with different fit perspectives has exacerbated the establishment of a cumulative research tradition in alignment research [5, p. 4]. More recently, alignment researchers increasingly employ Likert-type scales as direct measures, which have proven to be robust and appropriate for testing theories about the antecedents and outcomes of alignment [e.g., 30]. While alignment research has traditionally studied antecedents and consequences of alignment separately, more recent studies also consider alignment an important mediator [1, 40]. This present study adopts a direct measure of ISbusiness alignment to account for its hypothesized nomological role as a mediating mechanism in the ITSM-effectiveness relationship. 


\section{SUPPLEMENT C: MATURITY SCALE AND ATTRIBUTE DESCRIPTORS}

To assess the maturity of each ITSM practice reliably, as part of this research, we developed a detailed maturity matrix comprising multiple attributes that jointly determine the maturity of an organizational practice. The attributes refer to a) awareness and stakeholder communication, b) plans and procedures, c) tools and automation, d) skills and expertise, e) responsibility and accountability, and f) goal setting and measurement (see Table C1). In our online survey, each anchor of Table C1 was explained by a detailed descriptor realized as a small popup text. For example, "proactive control," the anchor for the goal setting attribute and measurement at maturity level 5 (optimized), was defined as a state in which "goal setting, measurement and control is integrated linking IT performance to business goals by a global application of causal analysis techniques" (a complete list of the all descriptors is available upon request). Respondents were instructed that the level of practice maturity is determined by the lowest maturity level of the criteria specified in the table. On the survey website, respondents first had to confirm they understood the maturity matrix before entering the assessment of the 26 ITSM practices.

Table C1. Process Maturity Matrix and Attribute Descriptors.

\begin{tabular}{|l|l|l|l|l|l|l|}
\hline Attributes & 0. None & 1. Initial & 2. Repeatable & 3. Defined & 4. Managed & 5. Optimized \\
\hline $\begin{array}{l}\text { a) Awareness } \\
\text { \& stakeholder } \\
\text { communication }\end{array}$ & no awareness & $\begin{array}{l}\text { partial } \\
\text { awareness }\end{array}$ & $\begin{array}{l}\text { wide } \\
\text { awareness }\end{array}$ & full awareness & $\begin{array}{l}\text { comprehensive } \\
\text { reporting }\end{array}$ & $\begin{array}{l}\text { proactive } \\
\text { communication }\end{array}$ \\
\hline $\begin{array}{l}\text { b) Plans \& } \\
\text { procedures }\end{array}$ & no process & $\begin{array}{l}\text { ad hoc } \\
\text { process }\end{array}$ & $\begin{array}{l}\text { informal } \\
\text { process }\end{array}$ & $\begin{array}{l}\text { formally } \\
\text { defined } \\
\text { process }\end{array}$ & $\begin{array}{l}\text { robust process } \\
\text { execution }\end{array}$ & $\begin{array}{l}\text { good practice } \\
\text { process }\end{array}$ \\
\hline $\begin{array}{l}\text { c) Tools \& } \\
\text { automation }\end{array}$ & no tools & $\begin{array}{l}\text { only standard } \\
\text { desktop tools }\end{array}$ & $\begin{array}{l}\text { individually } \\
\text { managed tools }\end{array}$ & $\begin{array}{l}\text { centrally } \\
\text { managed tools }\end{array}$ & $\begin{array}{l}\text { fully integrated } \\
\text { tools }\end{array}$ & $\begin{array}{l}\text { end-to-end } \\
\text { automation }\end{array}$ \\
\hline $\begin{array}{l}\text { d) Skills \& } \\
\text { expertise }\end{array}$ & $\begin{array}{l}\text { unknown } \\
\text { required skills }\end{array}$ & $\begin{array}{l}\text { identified } \\
\text { required } \\
\text { skills }\end{array}$ & $\begin{array}{l}\text { informal ad } \\
\text { hoc training }\end{array}$ & $\begin{array}{l}\text { formal training } \\
\text { plan }\end{array}$ & $\begin{array}{l}\text { long-term } \\
\text { training } \\
\text { program }\end{array}$ & $\begin{array}{l}\text { continuous } \\
\text { skill } \\
\text { improvement }\end{array}$ \\
\hline $\begin{array}{l}\text { e) } \\
\text { Responsibility } \\
\text { \& } \\
\text { accountability }\end{array}$ & $\begin{array}{l}\text { unknown } \\
\text { responsibilities }\end{array}$ & $\begin{array}{l}\text { responsibility } \\
\text { allocation }\end{array}$ & $\begin{array}{l}\text { informal } \\
\text { responsibilities }\end{array}$ & $\begin{array}{l}\text { defined } \\
\text { responsibilities }\end{array}$ & $\begin{array}{l}\text { fully } \\
\text { reschargeable } \\
\text { responsibilities }\end{array}$ & $\begin{array}{l}\text { harmonized } \\
\text { responsibilities }\end{array}$ \\
\hline $\begin{array}{l}\text { f) Goal setting } \\
\text { \& measurement }\end{array}$ & no goals & unclear goals & partial goals & $\begin{array}{l}\text { globally } \\
\text { defined goals }\end{array}$ & enforced goals & $\begin{array}{l}\text { proactive } \\
\text { control }\end{array}$ \\
\hline
\end{tabular}




\section{SUPPLEMENT D: FACTOR ANALYSIS RESULTS}

Table D1. Pattern Matrix and Factor Statistics (Oblique Rotation).

\begin{tabular}{|c|c|c|c|c|c|c|c|c|c|}
\hline & 1 & 2 & 3 & 4 & 5 & 6 & 7 & 8 & 9 \\
\hline SP1 & .46 & .237 & -.05 & -.04 & .11 & .03 & .12 & .04 & -.08 \\
\hline SP2 & .53 & .207 & .05 & -.17 & .09 & .03 & .05 & .01 & -.12 \\
\hline SP3 & .56 & .108 & .08 & -.18 & .21 & .09 & .06 & .06 & -.04 \\
\hline SP4 & .88 & -.001 & -.01 & .05 & -.01 & -.02 & -.03 & .01 & .01 \\
\hline SP5 & 1.02 & -.107 & -.07 & .04 & -.01 & .03 & -.04 & -.04 & -.03 \\
\hline SP6 & .80 & .034 & .09 & .04 & -.09 & -.04 & -.05 & .06 & .11 \\
\hline ST1 & -.03 & .745 & .17 & .11 & -.12 & .05 & -.00 & .06 & -.05 \\
\hline ST2 & -.05 & 1.008 & $-.1 \beta$ & -.03 & .05 & -.03 & .01 & -.03 & .01 \\
\hline ST3 & .18 & .588 & .08 & -.13 & .10 & -.05 & .02 & -.08 & .10 \\
\hline SO1 & .12 & .149 & .56 & .06 & .02 & .03 & .02 & -.04 & .02 \\
\hline $\mathrm{SO} 2$ & .16 & .095 & .63 & -.00 & -.15 & .01 & .09 & .07 & -.04 \\
\hline SO3 & -.11 & -.028 & .94 & .02 & -.01 & -.03 & -.01 & -.03 & .03 \\
\hline SO4 & -.03 & -.09 & .79 & -.07 & .12 & .03 & -.03 & -.04 & .05 \\
\hline SO5 & .29 & .01 & .53 & .07 & -.05 & -.00 & .01 & -.01 & -.03 \\
\hline E1 & .06 & -.07 & .02 & .81 & .01 & -.05 & .03 & .03 & -.03 \\
\hline E2 & DJ & .02 & .04 & .78 & .04 & -.01 & -.00 & .05 & .03 \\
\hline E3 & 17 & .06 & .04 & .85 & .02 & -.02 & -.01 & .05 & -.02 \\
\hline $\mathrm{E} 4$ & -.05 & -.00 & .01 & .78 & .09 & -.02 & .03 & .03 & -.05 \\
\hline E5 & .05 & .06 & -.12 & .77 & .12 & .03 & .02 & -.08 & .00 \\
\hline $\mathrm{A} 1$ & -.10 & -.05 & .14 & .10 & .77 & .04 & -.03 & .05 & -.02 \\
\hline A2 & -.05 & -.08 & .10 & -.02 & .87 & .05 & -.02 & .10 & -.08 \\
\hline A3 & .03 & .03 & -.08 & .05 & .88 & -.05 & -.03 & -.03 & .09 \\
\hline A4 & .05 & .06 & -.02 & .06 & .77 & -.04 & -.01 & .02 & -.02 \\
\hline A5 & .0 & .07 & -.07 & .07 & .80 & .04 & .01 & -.06 & .03 \\
\hline A6 & .01 & -.03 & .01 & .07 & .74 & .04 & .01 & -.07 & .03 \\
\hline I1 & .02 & -.07 & .03 & -.09 & .05 & .95 & .02 & .06 & -.00 \\
\hline $\mathrm{I} 2$ & .03 & .02 & -.08 & -.04 & .03 & .90 & .01 & .03 & -.02 \\
\hline I3 & -.05 & .01 & -.05 & .05 & .02 & .72 & .05 & -.20 & .12 \\
\hline $\mathrm{C} 2$ & .03 & -.13 & .03 & -.30 & .28 & -.14 & .61 & -.01 & .00 \\
\hline C3 & -.09 & -.01 & .01 & .08 & -.07 & .04 & 1.01 & .03 & .03 \\
\hline Sv1 & .02 & -.07 & .00 & .02 & .03 & -.00 & .02 & .94 & .02 \\
\hline Sv2 & .09 & .02 & -.16 & -.00 & .00 & .02 & .06 & .72 & .04 \\
\hline Reg1 & -.10 & .09 & .07 & -.08 & .04 & .00 & -.02 & .08 & .78 \\
\hline Reg2 & .16 & -.11 & .03 & .07 & -.06 & -.02 & .07 & -.04 & .69 \\
\hline V MA & & .03 & .03 & .03 & .02 & .02 & .02 & .02 & .02 \\
\hline $\mathrm{AdjBIC}^{1}$ & 2323 & 1271 & 913 & 570 & 283 & 134 & 39 & -57 & -133 \\
\hline Eigenv. $^{1}$ & 11.31 & 3.53 & 2.02 & 1.73 & 1.41 & 1.36 & .97 & .70 & .55 \\
\hline$\%$ var & .13 & .11 & .10 & .08 & .07 & .07 & .04 & .04 & .04 \\
\hline
\end{tabular}




\section{SUPPLEMENT E: TOTAL EFFECT MODERATION MODEL}

The regression model E5 with the interaction term conservativeness * alignment (Table E1) has a nonsignificant $\Delta R^{2}$ in relation to the regression model without this moderator term (see model $\mathrm{E} 4$ in Table 4 in the article). The analysis of simple effects in the total effect moderation model with Edward and Lambert's [8] bootstrapping procedure (1,000 bootstrapping samples) shows that the second stage as well as the indirect effect are not moderated by conservativeness (Table E2). These results show that the moderating effect of conservativeness on the capability-effectiveness relationship does not result from conservativeness moderating the link between alignment and effectiveness.

Table E1. Regression Model with Interaction Term Conservativeness * Alignment.

\begin{tabular}{|c|c|}
\hline Model: & $\begin{array}{l}\text { E5 } \\
\text { Full }\end{array}$ \\
\hline Dependent variable: & IS effectiveness \\
\hline \multicolumn{2}{|l|}{ Controls } \\
\hline Industry finance & $-.419(-1.458)$ \\
\hline Industry information \& communication & $-.064(-0.341)$ \\
\hline Industry manufacturing & $.103(0.832)$ \\
\hline Industry professional \& public services & $.000(0.003)$ \\
\hline Industry hospitality \& mobility & $.147(0.873)$ \\
\hline Industry utilities \& construction & $-.050(-0.844)$ \\
\hline HQ Americas & $.043(0.350)$ \\
\hline HQ Asia Pacific & $-.175(-1.332)$ \\
\hline Service orientation & $.003(0.082)$ \\
\hline Client size & $-.051(-0.725)$ \\
\hline Regulatory exposure & $.073(1.436)$ \\
\hline Horizontal position & $-.235^{+}(-1.932)$ \\
\hline Vertical position & $-.019(-0.278)$ \\
\hline Job tenure & $.139^{*}(2.142)$ \\
\hline \multicolumn{2}{|l|}{ Predictors } \\
\hline ITSM capability & $.169^{* * * *}(3.352)$ \\
\hline IS-business alignment & $.594^{* * *}(11.507)$ \\
\hline IS strategic conservativeness & $-.066(-1.460)$ \\
\hline \multicolumn{2}{|l|}{ Interactions } \\
\hline IS strategic conservativeness $*$ ITSM capability & $.057^{+}(1.792)$ \\
\hline IS strategic conservativeness $*$ IS-business alignment & $.006(0.182)$ \\
\hline$R^{2}(F)$ & $.604\left(17.79^{* * *}\right)$ \\
\hline$\Delta \mathrm{R}^{2}$ to model $\mathrm{E} 4$ (F-change) & $0.00 \%(0.033)$ \\
\hline
\end{tabular}


Table E2. Analysis of the Simple Effects in the Total Effect Moderation Model.

\begin{tabular}{|c|c|c|c|c|c|}
\hline & \multicolumn{2}{|c|}{ Stage } & \multicolumn{3}{|c|}{ Effects } \\
\hline Moderator $^{\mathrm{a}}$ & $\begin{array}{l}\text { First } \\
(\text { ITSM } \rightarrow \text { Align })\end{array}$ & $\begin{array}{l}\text { Second } \\
(\text { Align } \rightarrow \text { Effect })\end{array}$ & $\begin{array}{l}\text { Direct } \\
(I T S M \rightarrow E f f e c t)\end{array}$ & $\begin{array}{l}\text { Indirect } \\
(I T S M \rightarrow \text { Align } \rightarrow \text { Eff })\end{array}$ & $\begin{array}{l}\text { Total } \\
\text { (direct+indirect) }\end{array}$ \\
\hline High IS conservativeness & $.586^{* *}$ & $.596^{* *}$ & $.267^{* * *}$ & $.350^{* *}$ & $.617^{* *}$ \\
\hline Low IS conservativeness & $.393^{* * *}$ & $.579^{* *}$ & .096 & $.228^{* *}$ & $.323^{* *}$ \\
\hline Difference & $.193^{+}$ & .017 & $.172^{+}$ & .122 & $.294^{* *}$ \\
\hline
\end{tabular}

\section{SUPPLEMENT REFERENCES}

1. Bradley, R.V.; Pratt, R.M.; Byrd, T.A.; Outlay, C.N.; and Wynn Jr, D.E. Enterprise architecture, IT effectiveness and the mediating role of IT alignment in US hospitals. Information Systems Journal, 22, 2 (2012), 97-127.

2. Chan, Y.E.; Huff, S.L.; and Copeland, D.G. Assessing realized information systems strategy. The Journal of Strategic Information Systems, 6, 4 (1997), 273-298.

3. Chan, Y.E.; and Reich, B.H. IT alignment: What have we learned? Journal of Information Technology, 22, 4 (2007), 297-315.

4. Chien, S.-H.; and Chen, J.-J. Supplier involvement and customer involvement effect on new product development success in the financial service industry. The Service Industries Journal, 30, 2 (2010), 185-201.

5. Coltman, T.; Tallon, P.; Sharma, R.; and Queiroz, M. Strategic IT alignment: Twenty-five years on. Journal of Information Technology, 30, 2 (2015), 91-100.

6. Cots, S.; Casadesús, M.; and Marimon, F. Benefits of ISO 20000 IT service management certification. Information Systems and e-Business Management (2014), 1-18.

7. Dong, B.; Evans, K.R.; and Zou, S. The effects of customer participation in co-created service recovery. Journal of the Academy of Marketing Science, 36, 1 (2008), 123-137.

8. Edwards, J.R.; and Lambert, L.S. Methods for integrating moderation and mediation: A general analytical framework using moderated path analysis. Psychological Methods, 12, 1 (2007), 1-22.

9. Gacenga, F.; Cater-Steel, A.; Tan, W.-G.; and Toleman, M. IT service management: Towards a contingency theory of performance measurement. International Conference on Information Systems (ICIS 2011), 2011, pp. Paper 5.

10. Gacenga, F.; Cater-Steel, A.; and Toleman, M. An international analysis of IT service management benefits and performance measurement. Journal of Global Information Technology Management, 13, 4 (2010), 28-63.

11. Galliers, R.D. Reflections on information systems strategizing. In, Avgerou, C., Ciborra, C., and Land, F., (eds.), The social study of information and communication technology: Innovation, actors, and contexts, London: Oxford University Press, 2004, pp. 231-262.

12. Gerow, J.E.; Grover, V.; Thatcher, J.; and Roth, P.L. Looking toward the future of IT-business strategic alignment through the past: A meta-analysis. MIS Quarterly, 38, 4 (2014), 1059-1085.

13. Gerow, J.E.; Thatcher, J.B.; and Grover, V. Six types of IT-business strategic alignment: An investigation of the constructs and their measurement. European Journal of Information Systems, 24, 5 (2014), 1-27.

14. Grönroos, C.; and Voima, P. Critical service logic: Making sense of value creation and co-creation. Journal of the Academy of Marketing Science, 41, 2 (2013), 133-150. 
15. Henderson, J.C.; and Venkatraman, N. Strategic alignment: Leveraging information technology for transforming organizations. IBM Systems Journal, 32, 1 (1993), 472-484.

16. Hirschheim, R.; and Sabherwal, R. Detours in the path toward strategic information systems alignment. California Management Review, 44, 1 (2001), 87-108.

17. Hochstein, A.; Tamm, G.; and Brenner, W. Service oriented IT management: Benefit, cost and success factors. Proceedings of the 15th European Conference on Information Systems (ECIS 2005), Regensburg, Germany, 2005.

18. Iden, J.; and Eikebrokk, T.R. Implementing IT service management: A systematic literature review. International Journal of Information Management, 33, 3 (2013), 512-523.

19. Iden, J.; and Eikebrokk, T.R. The impact of senior management involvement, organisational commitment and group efficacy on ITIL implementation benefits. Information Systems and eBusiness Management (2014), 1-26.

20. Iden, J.; and Eikebrokk, T.R. Using the ITIL process reference model for realizing IT governance: An empirical investigation. Information Systems Management, 31, 1 (2014), 37-58.

21. Kashanchi, R.; and Toland, J. Can ITIL contribute to IT/business alignment? An initial investigation. Business \& Information Systems Engineering, 48, 5 (2006), 340-348.

22. Kearns, G.S.; and Lederer, A.L. A resource-based view of strategic IT alignment: How knowledge sharing creates competitive advantage. Decision Sciences, 34, 1 (2003), 1-29.

23. Marrone, M.; and Kolbe, L.M. Impact of IT service management frameworks on the IT organization. Business \& Information Systems Engineering, 3, 1 (2011), 5-18.

24. Marrone, M.; and Kolbe, L.M. Uncovering ITIL claims: IT executives' perception on benefits and Business-IT alignment. Information Systems and e-Business Management, 9, 3 (2011), 363-380.

25. Moura, A.; Sauve, J.; Jornada, J.; and Radziuk, E. A quantitative approach to IT investment allocation to improve business results. Policies for Distributed Systems and Networks, 2006. Policy 2006. Seventh IEEE International Workshop on: IEEE, 2006, pp. 9 pp.-95.

26. Nadler, D.A.; and Tushman, M.L. A model for diagnosing organizational behavior. Organizational Dynamics, 9, 2 (1980), 35-51.

27. Paulk, M.C.; Weber, C.V.; Garcia, S.M.; Chrissis, M.B.C.; and Bush, M. Key practices of the Capability Maturity Model version 1.1. Software Engineering Institute, Carnegie Mellon University, Pittsburgh, Pennsylvania, 1993.

28. Payne, A.F.; Storbacka, K.; and Frow, P. Managing the co-creation of value. Journal of the Academy of Marketing Science, 36, 1 (2008), 83-96.

29. Potgieter, B.; Botha, J.; and Lew, C. Evidence that use of the ITIL framework is effective. Proceedings to the 18th Annual Conference of the National Advisory Committee on Computing Qualifications, Tauranga, New Zealand, 2005, pp. 160-167.

30. Preston, D.S.; and Karahanna, E. Antecedents of IS strategic alignment: A nomological network. Information Systems Research, 20, 2 (2009), 159-179.

31. Pyburn, P.J. Linking the MIS plan with corporate strategy: An exploratory study. MIS Quarterly (1983), 1-14.

32. Reich, B.H.; and Benbasat, I. Factors that influence the social dimension of alignment between business and information technology objectives. MIS Quarterly, 24, 1 (2000), 81-113.

33. Sabherwal, R.; Hirschheim, R.; and Goles, T. The dynamics of alignment: Insights from a punctuated equilibrium model. Organization Science, 12, 2 (2001), 179-197.

34. Tiwana, A.; and Konsynski, B. Complementarities between organizational IT architecture and governance structure. Information Systems Research, 21, 2 (2010), 288-304.

35. Vargo, S.L.; and Lusch, R.F. Evolving to a new dominant logic for marketing. Journal of Marketing, 68, 1 (2004), 1-17.

36. Venkatraman, $\mathrm{N}$. The concept of fit in strategy research: Toward verbal and statistical correspondence. Academy of Management Review, 14, 3 (1989), 423-444. 
37. Wagner, H.-T. Managing the impact of IT on firm success: The link between the resource-based view and the IT infrastructure library. Proceedings of the 39th Annual Hawaii International Conference on System Sciences, 2006. HICSS'06. : IEEE, 2006, pp. 197c-197c.

38. Wagner, H.-T.; Beimborn, D.; and Weitzel, T. How social capital among information technology and business units drives operational alignment and IT business value. Journal of Management Information Systems, 31, 1 (2014), 241-272.

39. Wan, S.H.; and Chan, Y.-H. Improving service management in campus IT operations. CampusWide Information Systems, 25, 1 (2008), 30-49.

40. Wu, S.P.-J.; Straub, D.W.; and Liang, T.-P. How information technology governance mechanisms and strategic alignment influence organizational performance: Insights from a matched survey of business and IT managers. MIS Quarterly, 39, 2 (2015), 497-A497. 